\title{
Kişilik Özellikleri ile Hedonik Tüketim Değerleri Arasındaki İlişki Üzerine Bir İnceleme*
}

\author{
Sinan ÖZ**, Erdem TATLI**
}

\section{$\ddot{O} z$}

Bu araștırma hedonik tüketim değerleri ile kişilik özellikleri arasındaki ilişkinin incelenmesi amacıyla gerçekleştirilmiştir. Araştırma kapsamında ayrıca bireylerin hedonik tüketim değerlerinin, cinsiyet, medeni durum, yaş, gelir düzeyi ve eğitim düzeyi değisşkenleri açısından anlamlı derecede farklılaşıp farklılaşmadığı incelenmiştir. Araştırmanın katılımcı grubu İstanbul'da yaşayan 18 yaşından büyük ve lise mezunu olan bireylerden oluşmaktadır. Araştırmaya, 231'i (\%60.5) kadın ve 151'i (\%39.5) erkek olmak üzere toplam 382 birey katılmıştır. Araştırma genel tarama modellerinden, ilişsisel tarama modeli ile gerçekleştirilmiștir. Veri toplama aracı olarak bireylerin demografik bilgilerine ulaşmak amacıyla "Kişisel Bilgi Formu" kullanılmıștır. Ayrıca bireylerin hedonik tüketim değerlerini ölçmek için "Hedonik Tüketim Nedenleri Değisşkenleri Ölçeği", kişilik özelliklerini belirlemek için ise "Sıfatlara Dayalı Kişilik Testi" kullanılmıştır. Hedonik tüketim değerleri ile kişilik özellikleri arasındaki ilişkiyi belirlemek amacıyla Pearson Momentler Çarpımı Korelasyon Analizi yapılmıştır. Analiz sonucunda hedonik tüketim değerleri ile kişilik özellikleri arasında anlamlı ilişsilerin bulunduğu görülmüștür. "Ayrıca, bazı demografik özelliklere göre hedonik tüketim değerlerinin anlamlı olarak değiştiği tespit edilmiştir."

Anahtar Kelimeler: Kişilik Özellikleri, Hedonizm, Tüketim, Tüketici Araştırmaları, Tüketici Davranışları

\section{An Investigation on the Relationship Between Personality Properties and Hedonic Consumption} Values

\begin{abstract}
This research was carried out to examine the relationship between hedonic consumption values and personality traits. Within the scope of the research, it was also examined whether the hedonic consumption values of individuals differ significantly in terms of gender, marital status, age, income level and education level variables. The participant group of the research consists of individuals over 18 years old and high school graduates living in Istanbul. A total of 382 individuals, 231 (60.5\%) female and 151 (39.5\%) male, participated in the study. The research was carried out with relational scanning model, one of the general scanning models. As a data collection tool, "Personal Information Form" was used in order to reach the demographic information of the individuals. In addition, "Hedonic Consumption Reasons Variables Scale" was used to measure individuals' hedonic consumption values, and "Adjective Based Personality Test" was used to determine personality traits. Pearson Product Moment Correlation Analysis was conducted to determine the relationship
\end{abstract}

\footnotetext{
Özgün Araştırma Makalesi (Original Research Article)

Geliș/Received: 01.06 .2021

Kabul/Accepted: 03.09.2021

* Bu yayın, birinci yazarın İstanbul Ticaret Üniversitesi, Sosyal Bilimler Enstitüsü, Reklam ve Stratejik Marka İletişimi Programında Ağustos 2021 döneminde savunduğu ve Dr. Öğr. Üyesi Erdem TATLI danışmanlığında yürütülen yüksek lisans tezinden üretilmiştir.

${ }^{*}$ Uzman, İstanbul Ticaret Üniversitesi, Sosyal Bilimler Enstitüsü, Reklam ve Stratejik Marka İletişimi Programı, İstanbul, Türkiye, E-posta: sinanoz1994@gmail.com ORCID https://orcid.org/0000-00026580-4566

*** Dr. Öğr. Üyesi, İstanbul Ticaret Üniversitesi, İletişim Fakültesi, İstanbul, Türkiye,

E-posta: etatli@ticaret.edu.tr ORCID https://orcid.org/0000-0002-7512-5532
} 
Sinan Öz, Erdem Tatlı, "Kişilik Özellikleri ile Hedonik Tüketim Değerleri Arasındaki İlişki Üzerine Bir İnceleme", İzlek Akademik Dergi (Izlek Academical Journal), 4 (1), 2021, ss. 16-44.

between hedonic consumption values and personality traits. As a result of the analysis, it was seen that there were significant relationships between hedonic consumption values and personality traits.

Keywords: Personality Characteristics, Hedonism, Consumption, Consumer Research, Consumer Behaviours

\section{Giriş}

Kişilik oldukça karmaşık bir yapıdır ve psikoloji alan yazınında en geniş ve en çok tartışılan kavramlardan biridir. $\mathrm{Bu}$ nedenle kişiliğin tanımlanması oldukça zordur ve alan yazın incelendiğinde çok farklı kişilik tanımlarına rastlamak mümkündür. Temel anlamda kişilik, insanları diğer insanlardan ayıran, değişik yașam olayları karşısında ortaya koydukları nispeten kalıcı ve sabit özellikler bütünüdür. Bu anlamda kişilik, görece olarak kalıcı davranış, duygu ve tutumlar doğrultusunda insanların tepkilerini belirleyen faktörlerin önemlilerinden bir tanesidir (Taymur ve Türkçapar, 2012).

Değişen tüketim alışkanlıkları ve davranışlarıyla birlikte bireyler için tüketim motivasyon toplamak, haz yaşamak ve mutlu olmak için yapılan bir eylem, araç haline gelmiştir. Bu haz duygusunun da herhangi bir yeri ve zamanı yoktur. Dolayısıyla plansız olarak yapılan alışverişler tüketicilere daha çok zevk vermektedir. Plansız alışveriş tüketicilere macera, merak, korku, heyecan, eğlence, özgürlük vb. hisleri yaşatmaktadır. Anlık bu duygusal duyguları yaşayabilmek için tüketici hiç düşünmeden hareket edebilmektedir (Aytekin ve Ay, 2015). Bundan dolayı markalar, alışveriş sürecinin özellikle haz boyutunu da dikkate almalı ve ona göre planlama yapmalıdırlar.

Hazcllık kelimesi bireyin zevke odaklanmasını ifade ederken hedonik tüketimle alışverișten ve süreçten haz, zevk almak ifade edilmektedir. Çünkü günümüz tüketicileri bir ürün veya hizmete gereksinimleri olsun olmasın sadece haz almak adına bile satın alma davranışı göstermektedirler. Bundan dolayı anlık plansız satın alımları tetikleyen bireyin kişisel özellikleri, psikolojik ruh hali, mağazanın atmosferi, ürünlerin tasarımı, sıralanması vb. etkenler dikkate alınmalıdır (Öz ve Mucuk, 2015). Bu bilgiler doğrultusunda hazcı tüketicileri alışveriş sürecinden zevk alan, mutluluk duyan, macera, heyecan, eğlence arayan kişiler olarak tanımlamak mümkündür.

Bu doğrultuda araştırmanın amacı bireylerin sahip oldukları kişilik özellikleri ile hedonik tüketim değerleri arasındaki ilişkinin incelenmesi olarak belirlenmiştir. Araștırmada test edilecek ana hipotez ise "Kişilik özellikleri ile (nevrotizim, dişadönüklük, deneyime açıklık, yumuşakbaşlılık, sorumluluk) hedonik tüketim değerleri (macera, fırsat yakalama, başkalarını mutlu etme, fikir edinme, sosyalleşme, rahatlama) arasında istatistiksel olarak anlamlı bir ilişki bulunmaktadır" biçiminde belirlenmiştir.

$\mathrm{Bu}$ araştırma betimsel bir çalışma olup araştırmada bireylerin kişilik özellikleri ile hedonik tüketim değerleri arasındaki ilişkinin incelenmesi için ilişskisel tarama modeli kullanılmıştır. Bu model, genel tarama modellerinden bir tanesidir. Araştırmanın amacı doğrultusunda bireylerin demografik bilgilerini belirlemek için araştırmacının oluşturduğu kişisel bilgi formundan yararlanılmıştır. Ayrıca bireylerin hedonik tüketim değerlerini ölçmek için "Hedonik Tüketim Nedenleri Değişkenleri Ölçeği", kişilik özelliklerini belirlemek için ise "Sıfatlara Dayalı Kişilik Testi" kullanılmıştır. Verilerin analiz edilmesinde, IBM SPSS 22 paket programından yararlanılmıștır. Araștırma kapsamında hata payı .05 olarak kabul edilmiştir. Hedonik tüketim değerleri ile kişilik özellikleri arasındaki ilişkinin belirlenmesi için Pearson Momentler Çarpımı Korelasyon analizi yapılmıştır. Hedonik tüketim değerleri ile kişilik özellikleri arasındaki ilişkiyi 
belirlemek amacıyla Pearson Momentler Çarpımı Korelasyon Analizi yapılmıştır. Demografik özelliklere göre, hedonik tüketim değerlerinin incelenmesinde cinsiyete göre bağımsız gruplar için t-testi analizi, diğer değişkenlere göre (medeni durum, yaş, gelir düzeyi ve eğitim düzeyi) tek yönlü varyans analizi (ANOVA) kullanılmıştır.

\section{Kişilik Kavramının Genel Özellikleri}

Kişilik oldukça karmaşık bir yapıdır ve psikoloji alan yazınında en geniş ve en çok tartışılan kavramlardan biridir. Bu nedenle kişiliğin tanımlanması oldukça zordur ve alan yazın incelendiğinde çok farklı kişilik tanımlarına rastlamak mümkündür. Temel anlamda kişilik, insanları diğer insanlardan ayıran, değişik yaşam olayları karşısında ortaya koydukları nispeten kalıcı ve sabit özellikler bütünüdür. Bu anlamda kişilik, görece olarak kalıcı davranış, duygu ve tutumlar doğrultusunda insanların tepkilerini belirleyen faktörlerin önemlilerinden bir tanesidir (Taymur ve Türkçapar, 2012). Kişilik, insanların çevresine uyum sağlamak adına sergiledikleri davranışlarını ve fiziksel, bilişsel ve duyuşsal özelliklerini içerir (Vural, 2017). İnsanların hem kendi iç dünyasıyla hem de diğerleriyle kurmuş olduğu, onu diğerlerinden farklı kılan, görece kalıcl, tutarlı ve yapılaşmış özellikleridir (Saygın, 2014).

Ortak bir tanım yapıldığında kişilik, bireyin içsel kaynaklarından doğan ve bireyin davranışları yoluyla yansıyan, doğuştan gelen niteliklerin yanında deneme yanılma veya toplum tarafından öğrenilenleri de içeren, bireyin öğrenme, baş etme, algılama ve davranış örüntülerini etkileyen sürekli ve dinamik bir sistemdir (Aslan, 2008). Kişilik, bireylerin psikolojik dünyasına, duygu durumlarına ve sosyal davranışlarına etki etmektedir (Cervone ve Pervin, 2016; Erkuş, 1994).

Kişilik hakkında genel görüş kalıtım ve çevrenin etkisiyle oluştuğudur. Biyolojik faktörler, bireyin ebeveynlerinden gelen özelliklerin genetik yoluyla kuşaklar arasında aktarılmasını içeren kalıtımsal özelliklerdir (Çetin ve Beceren, 2007). Kişiliğin meydana gelmesinde bireyde doğuştan itibaren var olan biyolojik (kalıtımsal) özellikler önemli bir unsur olarak yer almaktadır. Biyolojik faktörler ile kast edilen yalnızca fiziksel özellikler değil aynı zamanda da öğrenme, zeka ve beceri kapasitelerini de kapsayan özelliklerdir (Zel, 2011).

Biyolojik faktörler kişiliği açıklamada tek başına yetersiz kalmaktadır. Çevrenin de biyolojik özellikler ile etkileşimde bulunarak kişilik oluşumu üzerinde ortak bir etki yarattığını söylemek mümkündür (Alkan, 2014; Tekin, 2012). Birey yaşamı doğduğu andan itibaren toplumun içerisinde varlığını devam ettirmektedir. Birey, içerisinde bulunduğu toplumdan etkilenir ve aynı zamanda içerisinde bulunduğu toplumu etkilemektedir. Bundan kaynaklı olarak toplumun kişilik üzerindeki etkisi oldukça önemli görülmektedir (Eroğlu, 2004).

Bireyin gözlemleme yoluyla elde ettiği öğrenmelerin kaynağı sosyokültüreldir. Bu öğrenilen davranışların da kişilik üzerinde etkisi bulunmaktadır. Kişilik üzerinde etkisi olan öğrenme, kalıcı davranış değişikliğini ifade etmektedir ve davranış değişiklikleri bireyin kişiliğini etkilemektedir (Erdoğan, 1991; Tezcan, 1987; Türk, 2007).

Kişilik üzerinde etkisi olan faktörlerden en önemlisinin aile olduğu kabul edilmektedir (Saltürk, 2008; Yazgan vd., 2004). Bebek dünyaya gözünü açtığı andan itibaren ailesiyle birliktedir. Bireyin ilk sosyalleștiği ve toplumsallaştığı birim olan aile, sosyal öğrenme sürecinin başladığı yerdir. Bireyin ihtiyaçlarının karşılanma düzeyi, ailedeki çocuk sayısı, doğum sırası, ebeveynlerin yaklaşımı, kardeşleriyle arasındaki yaş farkı gibi özelliklerin bireyin kişiliği üzerinde etkisi bulunmaktadır (Koptagel, 2001; Yakut, 2006). 
Bunların dişında kişilik gelişiminde etkili olan diğer faktörler, sosyal sınıf ve sosyal faktörler (Çakır, 2000; Güney, 2009; Silah, 2005), fiziki ve coğrafi faktörler (Ertürk, 2010; Zel, 2011), kitle iletişim araçları (Öktem, 2009) gibi faktörlerdir.

\section{Hedonizm ve Hedonik Tüketim}

Hedone, eski Yunancada haz ve zevk olarak ifade edilmektedir. Hazcllık olarak ifade edilen hedonizm kavramı ise, zevk kavramına düşkünlügü ifade eden, haz kavramına önem veren felsefi bir doktrin olarak karşımıza çıkmaktadır (Fırat ve Aydın, 2016). Hedonizmin ortaya çıkışı da Antik Yunan'a kadar uzanmaktadır ve M.Ö. dördüncü yüzyılda ortaya çıkmıştır (Odabaşı, 2017).

Hedonizm hazza olan aşırı bağlılığı ifade eder ve hayatın temel amacının zevk ile bağdaştırır (Çelik, 2009). İnsanların ideal yaşama ulaşmalarını duydukları haz ve hissettikleri zevk ile ilişkilendirmiştir (Kök ve Aksel, 2016). Hedonizmde daha çok duygusal zevklere önem verilir. Kişi, tüketim ve satın alma kararlarını hissettiği bu duygulara göre şekillendirir. İstek ve ihtiyaçlarını karşılamaktan ziyade; kişi için haz almak, kendini mutlu hissetmek ön plandadır (Baudrillard, 2004).

Hedonizmin öne çıkan önemli yönlerinden biri de kişinin yaptığı alışverişten ne beklediğidir. Alışveriş esnasında veya sonrasında oluşan beklentiler somut yararlardan daha fazlasını içerir. Hedonik beklentide soyut yararlar, hazlar, eğlence tarzları, düşler, hayaller, estetik görünüşler, arzular ön plandadır. Kişi; kendini daha özgür ve mutlu hissetmek, kendi ilgi alanındaki ihtiyaçlarını ortaya çıkarmak, acı hissettiği duygulardan kaçmak için hazsal alışveriş yapıp, hedonik tüketime yönelir (Çelik, 2009).

Hazcı tüketim, çoğunlukla anlık yapılan alışverişlerde zevk ve mutluluk yaratan duygusal doyumu ifade etmektedir. Duygusal doyum somut varlıkların elde edilmesiniz yanı sıra soyut düşüncelerin varlı̆̆ıyla bile sağlanabilmektedir (Babacan, 2001). Hedonizm felsefi bir kelimedir. Hedonizm hazcılık olarak da adlandırılmaktadır. Hedonizm, hayatta tek gerçek şeyin haz olduğunu savunmaktadır. Hedonizm zevk veren şeyi "iyi”, acı veren şeyi ise kötü olarak tanımlamaktadır. Epikür ise hazzı, huzur olarak tanımlamaktadır. Yani iyi olan şeylere yaklaşmayı, kötü olan şeylerden ise uzaklaşmayı öngörmektedir (Güven, 2009).

Hedonik tüketim de tüketicinin haz ve mutluluğu maksimum düzeydedir. Bu hazlar yaşanan deneyimler veya istenilen deneyimlerin soyut varlıklarıyla oluşmaktadır (Doğan vd., 2014). Ürün ve hizmetlerden olumlu, iyi duygular oluşturanlar hedonik ürün olarak adlandırılmaktadır (Hirschman ve Holbrook, 1982). Mağazanın iç ve dış atmosferi, tüketicilerin güdülerini olumlu yönde etkilemede etkendir (Chang, Eckman ve Yan, 2011). Örneğin, alışveriş sırasında mağazada çalan müzik, renkler, koku, resimler ya da bir dans gösterisi vb. tüketicin duygularını farklılaştırarak onlara eğlence ve zevk duygusunu yaşatmaktadır. Hedonist tüketicilerin merkezinde macera aramak, saygınlık görmek, değer kazanmak, fikir alışverişi yapmak, tatmin olmak, diğer tüketicilerle yarış içerisinde olmak gibi maddi olmayan birtakım nedenler bulunmaktadır (Ebrahimi, 2013). Bu tarz nedenler daha çok tüketicilerin plan ve programları olmadığında ortaya çıkmaktadır. Anlık ruh durumlarına göre alışveriş yapma nedenleri farklılık gösterebilmektedir. Bu değişsenlik durumundan mağaza sahipleri faydalanabilmektedir. Ruh halini ilk görüşte değiștirebilmek için öncelikle mağazanın atmosferine dikkat edilmelidir.

Hayattan iyiyi isteyen tüketici haz arayışına girmektedir. Bu durumda işletmeler tüketicilerin duygusal ihtiyaçlarına yönelmektedir. Artık tüketiciler ürünlerin deneyimsel boyutları ve sembolik anlamları ile ilgilenmektedir (Özgül, 2011). Ürünlerin fonksiyonel özelliklerinin önemi 
ikinci planda kalmıştır. Tüketici sahip olduğu marka deneyimi veya sembolü ile kendi iç dünyasını dışa yansıtmaktadır. Marka burada tüketicinin iç dünyası ve dış dünyası arasında aracı konumundadır. Tüketimcilik, hazzı hayatın ana amacı olarak görmektedir. Haz almak için bireylerin tüketime yöneldiğini savunur (Ceylan, 2007).

Hazza odaklanan tüketici isteklerini ertelemekten hoşlanmaz en kısa sürede elde etmek ister. Hedonist tüketiciler için maddelere sahip olmaktan çok bu süreçte yaşadıkları deneyim duyguları önemlidir (Coşkun, 2011). Bu süreçte duyusal ve duygusal uyarımlar sonucu tüketim gerçekleşmektedir. $\mathrm{Bu}$ uyarımlar sonucu oluşan tepkime de hedonik tepki olarak adlandırılmaktadır (Hirschman ve Holbrook, 1982). Karafakıoğlu (2013), güdüleri "gereksinimleri doğuran, bunun için yeterli enerjiye sahip güçlerdir" şeklinde tanımlamaktadır.

Hedonik tüketim sonucunda oluşan deneyim duygularını Hirschman ve Holbrook (1982) tanımlamışlardır. Bunlar (Hirschman ve Holbrook, 1982); Zevk, eğlence: Etkinliklere katılmak, konsere gitmek, yılbaşı kutlamaları vb. Duygusal zevk: Pahalı bir ev ve arabanın olması, lüks bir kafede oturmak vb. Duygusal deneyim: Sevdikleriyle vakit geçirmek, kişiler için özel olan günlerin kutlanması vb. Estetik zevk: Sanata ilgi duymak (müzik, resim, şiir) vb. Tüketim toplumlarında genel olarak anında tüketme isteği bulunmaktadır. Anında tüketme isteği tüketicileri hedonik tüketime yöneltmektedir. Hedonik tüketimde anında tatmin giderilmektedir. Hedonist birey sabırsızdır, çabuk ve hızlı bir şekilde isteklerini gerçekleştirmek ister. Günümüz tüketicisi doyumsuz ve hırslıdır. Her zaman daha fazlasını istemektedirler. Gelişen teknoloji ve sosyal medya ile birlikte tüketiciler gösterişe yönelmekte ve gereksinimleri dışında aşırı tüketim yapmaktan haz duymaktadırlar. Bu doğrultu da pazarlamacılar ve markalar tüketicilerin duygularına hitap edecek pazarlama stratejilerini geliştirmediler.

\section{Kişilik Özellikler ile Hedonik Tüketim Değerleri Arasındaki İlişki}

\subsection{Araștırmanın Amacı ve Konusu}

$\mathrm{Bu}$ araştırmada, bireylerin sahip oldukları kişilik özellikleri ile hedonik tüketim değerleri arasındaki ilişkinin incelenmesi amaçlanmıştır. Bununla birlikte bireylerin demografik özellikleri (cinsiyet, medeni durum, yaş, gelir düzeyi, eğitim düzeyi) ile hedonik tüketim değeri arasında anlamlı bir farklılık olup olmadı̆̆ incelenmektedir.

Alan yazın incelendiğinde kişiliğin tüketici davranışlarına etkisinin pek çok araştırmaya konu olduğu görülmektedir. Bireyin sahip olduğu kişilik özelliklerini tüketici davranış aşamalarında etken olan psikolojik faktörler arasında göstermek mümkündür. Bu kapsam dahilinde değerlendirilebilecek Schiffman ve Kanuk'un (2010) ifadelerine göre, başlangıçta psikoloji alanında davranışsal bozuklukların temeline yönelik bir konu olan ve buna odaklanan kişilik kavramı özellikle son yıllarda pazarlama uygulamaları açısından daha dikkat çekici bir alana dönüşmektedir. Çünkü kişilik özellikleri bireyin bir markayı fark etmesinde, elde ettiği bilgileri işleyerek değerlendirmesinde ve tüm bunlar sonucunda ürünü tercih etme eylemine bağlı olarak ikna mekanizmalarını harekete geçirmesinde önemli bir unsur haline gelmektedir. Bu noktada markaların, tüketicilerin kişilik özelliklerine yönelik olarak çalışmalarını düzenlemesi son derece normal gözükmektedir. Özellikle etkileşimli bir iletişim sürecini aktif kılan sosyal medya platformlarında gerçek zamanlı çalışmaların sıklıkla markalar tarafından kullanılması bir taraftan tüketicilerin kişilik özelliklerini kapsamlı bir şekilde ortaya koymalarını sağlarken, diğer taraftan elde ettikleri bu veriler sayesinde sonraki çalışmaları için stratejik bir uygulama denklemi oluşturmalarına yardımcı olmaktadır. Güzel bir örnek olarak, Udo-Imeh, Awara ve Essien'in (2015) çalışmalarında belirttikleri üzere, yapılan birçok ampirik çalışma tüketicilerin kendi kişilik 
özelliklerini yansıtan markaları daha sıklıkla tercih etme eğiliminde olduğunu göstermektedir. $\mathrm{Bu}$ nedenle markaların tüketicilere yönelik olarak bireyin iç ve dış çevresiyle bağlı bulunduğu ilişki yapılarını analiz ederek doğru hedef kitlelere etkin faaliyetlerle ulaşması hedeflenen başarının yakalanmasında oldukça önemli hale gelmektedir.

Bu noktada bireylerin kişilik özelliklerine göre hedonik tüketim değerleri arasındaki ilişkinin incelenmesinin, tüketici davranışlarını anlamak adına önemli bir konumda olduğu düşünülmektedir. Aynı zamanda günümüz dünyasında ortaya çıan değişimlerin sürekliliği, tüketicilerin beklentilerinin ve yaşam stillerinin de sürekli değişmesine neden olmaktadır. $\mathrm{Bu}$ nedenle tüketicileri tanımak adına yapılan güncel araştırmaların oldukça önemli olduğu düşünülmektedir.

$\mathrm{Bu}$ doğrultuda bu araştırmanın amacı, bireylerin sahip oldukları kişilik özellikleri ile hedonik tüketim değerleri arasındaki ilişkinin incelenmesi olarak belirlenmiştir.

\subsection{Hipotezler}

$\mathrm{Bu}$ araştırma kapsamında araştırmanın amacı doğrultusunda aşağıdaki hipotezlerin incelenmesi amaçlanmaktadır:

H1: Kişilik özellikleri ile (nevrotizim, dışadönüklük, deneyime açıklık, yumuşakbaşlılık, sorumluluk) hedonik tüketim değerleri (macera, fırsat yakalama, başkalarını mutlu etme, fikir edinme, sosyalleşme, rahatlama) arasında anlamlı bir ilişki bulunmaktadır.

H1a. Kişilik özellikleri ile (nevrotizim, dışadönüklük, deneyime açıklık, yumuşakbaşlılık, sorumluluk) hedonik tüketim değerleri ölçeği alt boyutu olan macera arasında anlamlı bir ilişki bulunmaktadır.

H1b. Kişilik özellikleri ile (nevrotizim, dışadönüklük, deneyime açlklık, yumuşakbaşlılık, sorumluluk) hedonik tüketim değerleri ölçeği alt boyutu olan firsat yakalama arasında anlamlı bir ilişki bulunmaktadır.

H1c. Kişilik özellikleri ile (nevrotizim, dışadönüklük, deneyime açıklık, yumuşakbaşlılık, sorumluluk) hedonik tüketim değerleri ölçeği alt boyutu olan başkalarını mutlu etme arasında anlamlı bir ilişki bulunmaktadır.

H1d. Kişilik özellikleri ile (nevrotizim, dışadönüklük, deneyime açıklık, yumuşakbaşlılık, sorumluluk) hedonik tüketim değerleri ölçeği alt boyutu olan fikir edinme arasında anlamlı bir ilişki bulunmaktadır.

H1e. Kişilik özellikleri ile (nevrotizim, dışadönüklük, deneyime açıklık, yumuşakbaşlılık, sorumluluk) hedonik tüketim değerleri ölçeği alt boyutu olan sosyalleşme arasında anlamlı bir ilişki bulunmaktadır.

H1f. Kişilik özellikleri ile (nevrotizim, dışadönüklük, deneyime açıklık, yumuşakbaşlılık, sorumluluk) hedonik tüketim değerleri ölçeği alt boyutu olan rahatlama arasında anlamlı bir ilişki bulunmaktadır.

H2: Hedonik tüketim değerleri (macera, firsat yakalama, başkalarını mutlu etme, fikir edinme, sosyalleşme, rahatlama) cinsiyet değişkenine göre farklılık göstermektedir.

H2a. Hedonik tüketim değerleri ölçeği alt boyutu olan rahatlama, cinsiyet değişkenine göre farklılık göstermektedir. 
H2b. Hedonik tüketim değerleri ölçeği alt boyutu olan firsat yakalama, cinsiyet değişkenine göre farklılık göstermektedir.

H2c. Hedonik tüketim değerleri ölçeği alt boyutu olan başkalarını mutlu etme, cinsiyet değişkenine göre farklılık göstermektedir.

H2d. Hedonik tüketim değerleri ölçeği alt boyutu olan fikir edinme, cinsiyet değişkenine göre farklılık göstermektedir.

H2e. Hedonik tüketim değerleri ölçeği alt boyutu olan sosyalleşme, cinsiyet değişkenine göre farklılık göstermektedir.

H2f. Hedonik tüketim değerleri ölçeği alt boyutu olan rahatlama, cinsiyet değişkenine göre farklılık göstermektedir.

H3: Hedonik tüketim değerleri (macera, firsat yakalama, başkalarını mutlu etme, fikir edinme, sosyalleşme, rahatlama) medeni durum değişkenine göre farklılık göstermektedir.

H3a. Hedonik tüketim değerleri ölçeği alt boyutu olan rahatlama, medeni durum değişkenine göre farklılık göstermektedir.

H3b. Hedonik tüketim değerleri ölçeği alt boyutu olan fırsat yakalama, medeni durum değişkenine göre farklılık göstermektedir.

H3c. Hedonik tüketim değerleri ölçeği alt boyutu olan başkalarını mutlu etme, medeni durum değişkenine göre farklılık göstermektedir.

H3d. Hedonik tüketim değerleri ölçeği alt boyutu olan fikir edinme, medeni durum değişkenine göre farklıllk göstermektedir.

H3e. Hedonik tüketim değerleri ölçeği alt boyutu olan sosyalleşme, medeni durum değişkenine göre farklılık göstermektedir.

H3f. Hedonik tüketim değerleri ölçeği alt boyutu olan rahatlama, medeni durum değişkenine göre farklıllk göstermektedir.

H4: Hedonik tüketim değerleri (macera, firsat yakalama, başkalarını mutlu etme, fikir edinme, sosyalleşme, rahatlama) yaş değişkenine göre farklılık göstermektedir.

H4a. Hedonik tüketim değerleri ölçeği alt boyutu olan rahatlama, yaş değişkenine göre farklılık göstermektedir.

H4b. Hedonik tüketim değerleri ölçeği alt boyutu olan firsat yakalama, yaş değişkenine göre farklılık göstermektedir.

H4c. Hedonik tüketim değerleri ölçeği alt boyutu olan başkalarını mutlu etme, yaş değişkenine göre farklıllk göstermektedir.

H4d. Hedonik tüketim değerleri ölçeği alt boyutu olan fikir edinme, yaş değişkenine göre farklılık göstermektedir.

H4e. Hedonik tüketim değerleri ölçeği alt boyutu olan sosyalleşme, yaş değişkenine göre farklılık göstermektedir. 
H4f. Hedonik tüketim değerleri ölçeği alt boyutu olan rahatlama, yaş değiş̧kenine göre farklılık göstermektedir.

H5: Hedonik tüketim değerleri (macera, firsat yakalama, başkalarını mutlu etme, fikir edinme, sosyalleşme, rahatlama) gelir düzeyi değişkenine göre farklılık göstermektedir.

H5a. Hedonik tüketim değerleri ölçeği alt boyutu olan rahatlama, gelir düzeyi değișkenine göre farklılık göstermektedir.

H5b. Hedonik tüketim değerleri ölçeği alt boyutu olan firsat yakalama, gelir düzeyi değișkenine göre farklıllk göstermektedir.

H5c. Hedonik tüketim değerleri ölçeği alt boyutu olan başkalarını mutlu etme, gelir düzeyi değişkenine göre farklılık göstermektedir.

H5d. Hedonik tüketim değerleri ölçeği alt boyutu olan fikir edinme, gelir düzeyi değişkenine göre farklılık göstermektedir.

H5e. Hedonik tüketim değerleri ölçeği alt boyutu olan sosyalleşme, gelir düzeyi değişkenine göre farklılık göstermektedir.

H5f. Hedonik tüketim değerleri ölçeği alt boyutu olan rahatlama, gelir düzeyi değişkenine göre farklılık göstermektedir.

H6: Hedonik tüketim değerleri (macera, firsat yakalama, başkalarını mutlu etme, fikir edinme, sosyalleşme, rahatlama) eğitim düzeyi değişkenine göre farklılık göstermektedir.

H6a. Hedonik tüketim değerleri ölçeği alt boyutu olan rahatlama, eğitim düzeyi değişkenine göre farklılık göstermektedir.

H6b. Hedonik tüketim değerleri ölçeği alt boyutu olan firsat yakalama, eğitim düzeyi değișkenine göre farklılık göstermektedir.

H6c. Hedonik tüketim değerleri ölçeği alt boyutu olan başkalarını mutlu etme, eğitim düzeyi değişkenine göre farklılık göstermektedir.

H6d. Hedonik tüketim değerleri ölçeği alt boyutu olan fikir edinme, eğitim düzeyi değişkenine göre farklıllk göstermektedir.

H6e. Hedonik tüketim değerleri ölçeği alt boyutu olan sosyalleşme, eğitim düzeyi değişkenine göre farklıllk göstermektedir.

H65f. Hedonik tüketim değerleri ölçeği alt boyutu olan rahatlama, eğitim düzeyi değişkenine göre farklılık göstermektedir.

\subsection{Araştırmanın Evreni ve Örneklemi}

Araştırma grubu, İstanbul'da yaşayan 18 yaşından büyük ve lise mezunu olan bireylerden oluşmaktadır. Araştırmaya dahil edilecek olan bireyler, olasılıksız örnekleme yöntemlerinden bir tanesi olan amaçlı örnekleme ve uygun örnekleme yöntemleriyle seçilmiştir.

Bir araştırmanın derinlemesine gerçekleştirilmesinde, araştırmanın amacı kapsamında bilgi bakımından zengin olan durumların seçilmesiyle bireylere ulaşılmasına amaçlı örnekleme ismi verilmektedir (Büyüköztürk vd., 2012). Amaçlı örnekleme, araştırmanın amacı doğrultusunda araştırmacı tarafından belirlenen niteliklere uygun olan katılımcıların araştırma kapsamında 
alınmasıyla gerçekleştirilmektedir (Etikan vd 2016). Bu araştırma doğrultusunda da bireyler seçilirken iki temel ölçüt belirlenmiştir. İlk ölçüt, katılımcıların eğitim seviyelerinin en az lise düzeyinde olmasıdır. Bu ölçüt, veri toplama araçlarındaki soruların daha doğru anlaşılıp daha bilinçli yanıtlandırılması için önemli bulunmuştur. Diğer ölçüt katılımcıların 18 yaşın üzerinde olmalarıdır. Bu ölçüt ise araştırmanın herhangi bir etik sorun teşkil etmemesi bakımından önemli görülmüştür.

Bu ölçütlere uygun bireylere ulaşmak amacıyla uygun örnekleme yönteminden yararlanılmıştır. Uygun örnekleme işgücü, zaman ve para açısından sınırlı durumda olunması sonucunda araştırmaya katılan bireylerin uygulama yapılabilir ve kolay ulaşılabilir biçimde seçilmesi olarak ifade edilmektedir (Büyüköztürk vd., 2012). Uygun örneklemenin tercih edilmesinin sebebi araştırmacının katılımcılara pratik ve kolay bir biçimde ulaşmasını sağlamasıdır.

Bu araştırma kapsamında 382 bireye ulaşılmıștır. Bu araştırmanın evreni İstanbul'da yaşayan 18 yaşından büyük ve lise mezunu olan bireylerden oluşmaktadır. İstanbul'da yaşayan nüfus yaklaşık olarak 16 milyondur (TUIK, 2021). Buradan hareketle İstanbul'da yaşayan 18 yaşından büyük ve lise mezunu olan birey sayısının 6,5 milyon civarında olduğu hesaplanmıştır. Yazıcıoğlu ve Erdoğan (2004), .05 hata payı ile 1 milyondan büyük evrenler için 384 örneklem seçilmesinin uygun olacağını belirtmektedir. Bu nedenle araştırmada ulaşılan örneklem grubunun evreni temsil ettiği söylenebilir. Bu doğrultuda araştırmanın örneklem grubunu, 18 yaşından büyük ve en az lise mezunu olan 382 birey oluşturmaktadır. Örneklem grubunu oluşturan bireylere ait demografik bilgilere Tablo 1'de yer verilmiştir.

\begin{tabular}{|l|l|l|l|l|l|}
\hline Değişken & f & $\mathbf{\%}$ & Değişken & f & \% \\
\hline Cinsiyet & & & Yaş & & \\
\hline Kadın & 231 & 60.5 & $\mathbf{1 8 - 2 5}$ & 102 & 26.7 \\
\hline Erkek & 151 & 39.5 & $\mathbf{2 6 - 3 5}$ & 137 & 35.9 \\
\hline Medeni Durum & & & $\mathbf{3 6 - 4 5}$ & 91 & 23.8 \\
\hline Evli & 208 & 54.5 & $\mathbf{4 6}$ ve üzeri & 52 & 13.6 \\
\hline Bekar & 154 & 40.3 & Ĕgitim Düzeyi & & \\
\hline Eşinden ayrı/Eşi vefat eden & 20 & 5.2 & Lise & 97 & 25.4 \\
\hline Gelir Düzeyi & & & Ön lisans & 42 & 11.0 \\
\hline 2500 ve altı & 96 & 25.1 & Lisans & 177 & 46.3 \\
\hline 2501-5000 & 132 & 34.6 & Lisansüstü & 66 & 17.3 \\
\hline 5000 ve üzeri & 154 & 40.3 & & & \\
\hline Toplam & 382 & 100 & Toplam & 382 & 100 \\
\hline
\end{tabular}

Tablo 1: Araştırma Grubuna Ait Demografik Bilgilerin Frekans ve Yüzdelik Değerleri

\subsection{Araştırmanın Modeli}

$\mathrm{Bu}$ araştırma betimsel bir çalışma olup araştırmada bireylerin kişilik özellikleri ile hedonik tüketim değerleri arasındaki ilişkinin incelenmesi için ilişkisel tarama modeli kullanılmıştır. Bu model, genel tarama modellerinden bir tanesidir. Tarama modellerinde belirlenmiş bir evren ile 
ilgili genel geçer bir bilgiye sahip olmak amaçlanmaktadır. Bu kapsamda yapılan araştırmalar evrenin bütünü veya evrenin içerisinden alınan bir örneklem üzerinden gerçekleştirilir. İlişkisel tarama modellerinde ise iki ya da ikiden fazla değişkenin bir arada değişip değişmediğini ve ortaya çıkan değişimin ne derece ne yönde ve ne büyüklükte olduğunu açılamak hedeflenmektedir. İlişkisel tarama modeli ile elde edilen ilişkiler, gerçek neden sonuç ilişkisini yansıtmaz ve bu doğrultuda yorumlanamazlar. Ancak değişkenlerin neden sonuç ilişkileri hakkında ipucu verebilmektedirler. Bununla birlikte incelenen bir değişkendeki durumun belirlenmesiyle diğer değişken ile ilgili olarak çıkarımda bulunulmasına imkan sağlar (Karasar, 2018).

\subsection{Veri Toplama Araçları}

Araştırmanın amacı doğrultusunda bireylerin demografik bilgilerini belirlemek için araştırmacının oluşturduğu kişisel bilgi formundan yararlanılmıştır. Bununla birlikte bireylerin hedonik tüketim değerlerini ölçmek için "Hedonik Tüketim Nedenleri Değişkenleri Ölçeği”, kişilik özelliklerini belirlemek için ise "Sıfatlara Dayalı Kişilik Testi” kullanılmıştır. Kullanılan araçlarla ilgili bilgiler aşağıda bulunmaktadır.

Kişisel Bilgi Formu: Araştırmanın amacı doğrultusunda, araştırmaya dahil olan kişilerin kişisel bilgilerine ulaşmak amacıyla araştırmacı tarafından oluşturulmuştur. Bu formda; cinsiyet, medeni durum, yaş, gelir düzeyi ve eğitim düzeyi özelliklerini belirlemeye yönelik sorular yer almaktadır (Ek1).

Hedonik Tüketim Nedenleri Değişkenleri Ölçeği: Hedonik Tüketim Nedenleri Değişkenleri Ölçeği, bireylerin hedonik tüketim davranışlarının nedenlerini belirlemek amacıyla Arnold ve Reynolds'un (2003) geliştirilmiştir. Ölçek Ünal ve Ceylan (2008) tarafından Türkçe'ye uyarlanmıştır. Ölçek, 23 madde ve 6 alt boyuttan oluşmakta ve 4'lü Likert tipinde cevaplandırılmaktadır (Ek2). Ölçekteki boyutlar; macera, fırsat yakalama, başkalarını mutlu etme, fikir edinme, sosyalleşme ve rahatlama olarak isimlendirilmiştir.

Sıfatlara Dayalı Kişilik Testi: Sıfatlara Dayalı Kişilik Testi, Bacanlı, İlhan ve Aslan (2009) tarafından Beş Faktörlü Kişilik Kuramı'ndan yola çıkılarak geliştirilmiştir. Beş Faktörlü Kişilik Kuramı'ndaki faktörlere uygun olan sıfat çiftlerinin kullanıldığı ölçek, iki uçlu olarak geliştirilmiştir. Ölçek, birbirine zıt 40 sıfat çiftinden oluşmakta ve 7'li Likert tipinde cevaplandırılmaktadır (Ek3). Cevaplandırma sırasında ölçeği uygulayan kişiden kendisini her iki uçta yer alan sıfatlardan hangisine daha yakın görüyorsa ilgili boşluğu doldurması istenir. Yapılan analizler sonucunda ölçeğin 5 faktörlü bir yapı ortaya koyduğu sonucuna ulaşılmıştır. Bu faktörler; duygusal dengesizlik/nevrotizm, dışadönüklük, deneyime açıklık, yumuşakbaşlılık ve sorumluluk olarak isimlendirilmiştir.

\subsection{Analiz Süreci ve Adımları}

Araştırma doğrultusunda veri toplanacak olan ölçme araçlarının kullanılması adına gerekli olan izinler alınmış ve ölçme araçları bir araya toplanarak veri toplama seti meydana getirilmiştir. Araştırmaya katılan bireylere ilk olarak araştırmanın neden yapıldığı, verilerin gizliliği ve verilerin ne şekilde doldurulması gerektiğinin açıklaması yapılmıştır. Ölçme araçları, araştırmaya katılım göstermeye gönüllü olan bireylere ulaştırılmıştır. Veri toplama araçları, pandemi süreci nedeniyle elektornik ortam aracılığıyla katılımcılara ulaştırılmıştır. Bu nedende veri seti, Google Form kullanılarak link haline getirilmiştir. Araștırma doğrultusunda 382 bireye ulaşılmıştır. 
Veriler 2021 senesinin Ocak ayında toplanmıștır. Bireylerin veri setini tamamlamalarının yaklaşık 10 dakika sürdüğü tahmin edilmektedir.

Verilerin analiz edilmesinde, IBM SPSS 22 paket programından yararlanılmıştır. Araştırma kapsamında hata payı 05 olarak kabul edilmiştir. Hedonik tüketim değerleri ile kişilik özellikleri arasındaki ilişkinin belirlenmesi için Pearson Momentler Çarpımı Korelasyon analizi yapılmıștır. Ancak öncelikle verilerin normal dağılım gösterip göstermediğinin test edilmesi için gerekli analizler yapılmıştır. İlk olarak verilerin normal dağılıma uygunluğunun kontrol edilmesi için uç değerlere bakılmış bu doğrultuda değişkenlerin basıklık ve çarpıklık değerleri incelenmiştir. Basıklık ve çarpıklık değerlerinin +1 ve -1 arasında olması halinde verilerin normal dağıldı̆̆ı ifade edilmektedir (Çokluk vd., 2016). Basıklık ve çarpıklık değerlerine bakıldığında tüm verilerin bu şarta uyduğu ancak her bir ölçek toplam puanına bakıldığında kutu grafiklerinde normal dağılımın dışında kalan ortak verilerin olduğu görülmüştür. Bu verilerden 5 tanesi analiz dışında bırakılarak verilerin normal dağılıma yaklaşması sağlanmaya çalışılmıştır. Verilerin basıklık ve çarpıklık değerlerinin yer aldığı bilgiler Tablo 2'de yer almaktadır.

\begin{tabular}{|l|l|l|}
\hline Değişken & Basıklık & Çarpıklık \\
\hline Macera & -.895 & .136 \\
\hline Firsat yakalama & -.854 & -.204 \\
\hline Başkalarını mutlu etme & -.306 & -.816 \\
\hline Fikir edinme & -.631 & .469 \\
\hline Sosyalleşme & -.572 & .443 \\
\hline Rahatlama & -.983 & -.01 \\
\hline Nevrotizm/Duygusal dengesizlik & -.323 & .303 \\
\hline Dışadönüklük & .023 & -.639 \\
\hline Deneyime açıklık & .665 & -.706 \\
\hline Yumuşakbaşlılık & .082 & -.529 \\
\hline Sorumluluk & .461 & -.697 \\
\hline
\end{tabular}

Tablo 2. Değişkenlere Ait Basıklık ve Çarpıklık Değerleri

Normalliğin değerlendirilmesi adına yapılan bir diğer analiz ise Kolmogrov-Smirnov testidir. Bu test sonucunda verilerin normal dağılım göstermediği sonucuna ulaşılmıştır. Alan yazında örneklem büyüklüğünün genişlemesi ile birlikte küçük farklılıkların manidar çıkma ihtimalinin artabildiği, bu nedenle de verilerin basıklık ve çarpıklık değerlerinin istenilen koşulları sağlamasının, dağılımın normalden aşırı sapma göstermediğinin bir kanıtı olarak kabul edilebileceği belirtilmektedir (Çokluk, Şekercioğlu ve Büyüköztürk, 2016). Bununla brilikte normal Q-Q grafiğine bakılmış ve bu grafik üzerindeki noktaların 45 derecelik doğru üzerinde veya yakınında bulunduğu (Büyüköztürk, 2011; Can, 2017) görülmüștür. Yapılan tüm bu incelemeler sonucunda verilerin normal dağılım gösterdiği kabul edilerek analizler gerçekleştirilmiştir. 


\subsection{Araştırmaya İlişkin Ulaşılan Temel Bulgular}

Araştırmanın bu bölümünde araştırmanın hipotezlerinin test edilmesi adına incelenen verilerin istatistiksel sonuçlarına dair bulgular bulunmaktadır. İlk olarak değişkenlere ait betimsel istatistiklere ardından araştırma hipotezlerinden yola çıkılarak ulaşılan bulgulara yer verilmiștir.

\subsubsection{Hedonik Tüketim Değerleri ve Kişilik Özelliklerine Yönelik Betimsel İstatistikler}

Araştırmanın yürütüldüğü örneklem grubunda yer alan bireylerin hedonik tüketim değerleri ile kişilik özellikleri puanlarına ait ortalama, standart sapma. ranj, ve maksimum değerlerine Tablo 3'te yer verilmiştir.

\begin{tabular}{|l|l|c|l|l|l|l|l|}
\hline & $\mathbf{n}$ & $\underline{X}$ & SS & Shx & Ranj & Maks & Min. \\
\hline Macera & 377 & 11.31 & 4.84 & .24 & 16 & 20 & 4 \\
\hline Firsat Yakalama & 377 & 13.08 & 4.21 & .21 & 16 & 20 & 4 \\
\hline Başkalarını Mutlu Etme & 377 & 15.77 & 4.31 & .22 & 16 & 20 & 4 \\
\hline Fikir Edinme & 377 & 9.57 & 4.36 & .22 & 16 & 20 & 4 \\
\hline Sosyalleşme & 377 & 10.07 & 4.37 & .22 & 16 & 20 & 4 \\
\hline Rahatlama & 377 & 9.01 & 4.23 & .21 & 12 & 15 & 3 \\
\hline Duygusal Dengesizlik & 377 & 25.55 & 7.36 & .37 & 37 & 46 & 9 \\
\hline Dışadönüklük & 377 & 48.17 & 9.48 & .48 & 46 & 63 & 17 \\
\hline Deneyime Açıklık & 377 & 44.94 & 6.57 & .33 & 35 & 56 & 21 \\
\hline Uyumluluk & 377 & 50.55 & 7.30 & .37 & 39 & 63 & 24 \\
\hline Sorumluluk & 377 & 38.61 & 6.72 & .34 & 36 & 49 & 13 \\
\hline
\end{tabular}

Tablo 3. Değiş̧kenlere Ait Betimsel İstatistikler

Tablo 3'te görüldüğü gibi Hedonik Tüketim Nedenleri Değişkenleri Ölçeği'nin alt boyutlarına bakıldığında macera alt boyutuna bakıldığında aritmetik ortalaması 11.31 (SS=4.84)'dir. Bu ölçekten alınabilecek en yüksek puan 20 iken en düşük puan 4'tür. Firsat yakalama alt boyutuna bakıldığında aritmetik ortalaması 13.08 (SS=4.21)'dir. Bu ölçekten alınabilecek en yüksek puan 20 iken en düşük puan 4'tür. Başkalarını mutlu etme alt boyutuna bakıldığında aritmetik ortalaması 15.77 (SS=4.31)'dir. Bu ölçekten alınabilecek en yüksek puan 20 iken en düşük puan 4'tür. Fikir edinme alt boyutuna bakıldığında aritmetik ortalaması 9.57 ( $S S=4.36$ )'dir. Bu ölçekten alınabilecek en yüksek puan 20 iken en düşük puan 4'tür. Sosyalleşme alt boyutuna bakıldığında aritmetik ortalaması 10.07 (SS=4.37)'dir. Bu ölçekten alınabilecek en yüksek puan 20 iken en düşük puan 4'tür. Rahatlama alt boyutuna bakıldığında aritmetik ortalaması 9.01 (SS=4.23)'dir. Bu ölçekten alınabilecek en yüksek puan 15 iken en düşük puan 3'tür.

Sıfatlara Dayalı Kişilik Testi'nin alt boyutlarına bakıldığında duygusal dengesizlik alt boyutunun aritmetik ortalaması 25.55 (SS=7.36)'tir. Bu boyuttan alınabilecek en yüksek puan 63, en düşük puan ise 9'dur. Dışadönüklük alt boyutunun aritmetik ortalaması 48.17 (SS=9.48)'dir. Bu boyuttan alınabilecek en yüksek puan 63, en düşük puan ise 9'dur. Deneyime açıklık alt boyutunun 
aritmetik ortalaması 44.94 (SS=6.57)'tür. Bu boyuttan alınabilecek en yüksek puan 49, en düşük puan ise 7'dir.

Uyumluluk alt boyutunun aritmetik ortalaması 50.55 (SS=7.30)'tir. Bu boyuttan alınabilecek en yüksek puan 49, en düşük puan ise 7'dir. Sorumluluk alt boyutunun aritmetik ortalaması 38.61 (SS=6.72)'dir. Bu boyuttan alınabilecek en yüksek puan 56, en düşük puan ise 8'dir.

\subsubsection{Hedonik Tüketim Değerleri ve Kişilik Özellikleri Arasındaki İlişkinin İncelenmesine Yönelik Bulgular}

\begin{tabular}{|c|c|c|c|c|c|c|c|c|c|c|c|}
\hline Değişkenler & 1 & 2 & 3 & 4 & 5 & 6 & 7 & 8 & 9 & 10 & 11 \\
\hline 1. Macera & 1.00 & & & & & & & & & & \\
\hline 2. Firsat Yakalama & $.38^{* *}$ & 1.00 & & & & & & & & & \\
\hline $\begin{array}{l}\text { 3. Başkalarını } \\
\text { Mutlu Etme }\end{array}$ & $.35^{* *}$ & $.26^{* *}$ & 1.00 & & & & & & & & \\
\hline 4. Fikir Edinme & $.61^{* *}$ & $.28^{* *}$ & $.25^{* *}$ & 1.00 & & & & & & & \\
\hline 5. Sosyalleşme & $.52^{* *}$ & $.32^{* *}$ & $.34^{* *}$ & $.63^{* *}$ & 1.00 & & & & & & \\
\hline 6. Rahatlama & $.76^{* *}$ & $.30^{* *}$ & $.35^{* *}$ & $.58^{* *}$ & $.53^{* *}$ & 1.00 & & & & & \\
\hline $\begin{array}{l}\text { 7. Duygusal } \\
\text { Dengesizlik }\end{array}$ & $.11^{*}$ & $.17^{* *}$ & .05 & $.12^{*}$ & $.14^{* *}$ & $.13^{*}$ & 1.00 & & & & \\
\hline 8. Dışadönüklük & $.31^{* *}$ & $.12^{*}$ & $.21^{* *}$ & $.24^{* *}$ & $.26^{* *}$ & $.27^{* *}$ & $.16^{* *}$ & 1.00 & & & \\
\hline $\begin{array}{l}\text { 9. Deneyime } \\
\text { Açıklık }\end{array}$ & .09 & .05 & $.13^{*}$ & .12 & $.12^{*}$ & .09 & -.09 & $.55^{* *}$ & 1.00 & & \\
\hline 10. Uyumluluk & .06 & .06 & $.24^{* *}$ & .02 & $.11^{*}$ & .06 & $.21^{* *}$ & $.34^{* *}$ & $.21^{* *}$ & 1.00 & \\
\hline 11. Sorumluluk & $.11^{*}$ & .06 & $.13^{*}$ & .10 & $.14^{* *}$ & .10 & $-17^{* *}$ & $.53^{* *}$ & $.25^{* *}$ & $.37^{* *}$ & 1.00 \\
\hline
\end{tabular}

${ }^{* *} \mathrm{p}<.01,{ }^{*} \mathrm{p}<.05 \quad$ Tablo 4. Pearson Momentler Çarpımı Korelasyon Analizi Sonuçları

$\mathrm{Bu}$ araştırmanın amacı doğrultusunda incelenen 1. Hipotez, "Kişilik özellikleri ile (nevrotizim, dışadönüklük, deneyime açıklık, yumuşakbaşlılık, sorumluluk) hedonik tüketim değerleri (macera, fırsat yakalama, başkalarını mutlu etme, fikir edinme, sosyalleşme, rahatlama) arasında istatistiksel olarak anlamlı bir ilişki bulunmaktadır." şeklindedir. Bu hipotezin test edilmesi için Pearson Momentler Çarpımı Korelasyon Analizi uygulanmıştır. Uygulanan analizin sonuçları Tablo 4'te yer almaktadır.

Büyüköztürk'e (2011) göre korelasyon analizleri yorumlanırken .00 ile .30 arasında kalan değerler "düşük"; .31 ile .70 arasında kalan değerler "orta"; .71 ve üzerinde yer alan değerler ise "yüksek" olarak kabul edilmektedir.

Gerçekleştirilen korelasyon analizinden elde edilen sonuçlar bu yönde yorumlandığında, Tablo 4'te yer aldığı gibi, hedonik tüketim değerlerinden macera ile dışadönüklük $(\mathrm{r}=.31 ; \mathrm{p}<.01)$ 
arasında orta düzeyde, duygusal dengesizlik $(\mathrm{r}=.11 ; \mathrm{p}<.05)$ ve sorumluluk $(\mathrm{r}=.11 ; \mathrm{p}<.05)$ arasında düşük düzeyde ve pozitif yönde anlamlı bir ilişki olduğu görülmektedir.

Fırsat yakalama ile duygusal dengesizlik $(\mathrm{r}=.17 ; \mathrm{p}<.01)$ ve dışadönüklük $(\mathrm{r}=.12 ; \mathrm{p}<.05)$ arasında düşük düzeyde ve pozitif yönde anlamlı bir ilişki olduğu görülmektedir.

Başkalarını mutlu etme ile dışadönüklük ( $\mathrm{r}=.21 ; \mathrm{p}<.01)$, deneyime açıklık $(\mathrm{r}=.13 ; \mathrm{p}<.05)$, uyumluluk $(\mathrm{r}=.24 ; \mathrm{p}<.01)$ ve sorumluluk $(\mathrm{r}=.13$; $\mathrm{p}<.05)$ arasında düşük düzeyde ve pozitif yönde anlamlı bir ilişki olduğu görülmektedir.

Fikir edinme ile duygusal dengesizlik $(\mathrm{r}=.12 ; \mathrm{p}<.05)$ ve dışadönüklük $(\mathrm{r}=.24 ; \mathrm{p}<.01)$ arasında düşük düzeyde ve pozitif yönde anlamlı bir ilişki olduğu görülmektedir.

Sosyalleşme ile duygusal dengesizlik ( $\mathrm{r}=.14 ; \mathrm{p}<.01)$, dışadönüklük $(\mathrm{r}=.26 ; \mathrm{p}<.01)$, deneyime açıklık ( $\mathrm{r}=.12 ; \mathrm{p}<.05)$, yumuşakbaşlılık $(\mathrm{r}=.11 ; \mathrm{p}<.05)$ ve sorumluluk $(\mathrm{r}=.14 ; \mathrm{p}<.01)$ arasında düşük düzeyde ve pozitif yönde anlamlı bir ilişki olduğu görülmektedir.

Rahatlama ile duygusal dengesizlik $(\mathrm{r}=.13 ; \mathrm{p}<.05)$ ve dışadönüklük $(\mathrm{r}=.27 ; \mathrm{p}<.01)$ arasında düşük düzeyde ve pozitif yönde anlamlı bir ilişki olduğu görülmektedir.

Bu doğrultuda H1 hipotezinin kabul edildiği görülmektedir.

\subsubsection{Demografik Değişkenlerin Hedonik Tüketim Değerleri Üzerindeki Etkisinin İncelenmesine Yönelik Bulgular}

Hedonik tüketim değerlerinin demografik değişkenlere (cinsiyet, medeni durum, yaş, gelir düzeyi ve eğitim düzeyi) göre farklılaşıp farklılaşmadığını belirlemek için Bağımsız Gruplar t-testi ve Tek Yönlü Varyans Analizi (ANOVA) yapılmıştır.

\subsubsection{Cinsiyete Göre Hedonik Tüketim Değerleri}

Bireylerin hedonik tüketim değerlerinde cinsiyet açısından istatistiksel olarak anlamlı bir farklılık bulunup bulunmadığını tespit etmek için bağımsız gruplar için t-testi analizi gerçekleştirilmiştir. Analiz gerçekleștirilmeden önce varyansların homojen olup olmadığına Levene testi ile bakılmış, ve homojen olduğu görülmüştür. Ardından aritmetik ortamalar arasında bulunan farkın incelenmesi adına bağımsız gruplar t-testi analizi gerçekleştirilmiştir. Analiz sonuçları Tablo 5 'te yer almaktadır. 
Sinan Öz, Erdem Tatlı, "Kişilik Özellikleri ile Hedonik Tüketim Değerleri Arasındaki İlişki Üzerine Bir İnceleme”, İzlek Akademik Dergi (Izlek Academical Journal), 4 (1), 2021, ss. 16-44.

\begin{tabular}{|c|c|c|c|c|c|c|c|}
\hline & Cinsiyet & $\mathbf{n}$ & $\underline{X}$ & SS & Sd & $\mathbf{t}$ & $\mathbf{p}$ \\
\hline \multirow[t]{2}{*}{ Macera } & Kadın & 226 & 12.53 & 4.98 & .33 & 6.600 & $.000^{*}$ \\
\hline & Erkek & 151 & 9.47 & 3.98 & .32 & & \\
\hline \multirow{2}{*}{ Firsat Yakalama } & Kadın & 226 & 13.75 & 4.00 & .26 & 3.842 & $.000^{*}$ \\
\hline & Erkek & 151 & 12.07 & 4.34 & .35 & & \\
\hline \multirow{2}{*}{ Başkalarını Mutlu Etme } & Kadın & 226 & 16.72 & 3.82 & .25 & 5.195 & $.000^{*}$ \\
\hline & Erkek & 151 & 14.36 & 4.62 & .37 & & \\
\hline \multirow{2}{*}{ Fikir Edinme } & Kadın & 226 & 10.29 & 4.62 & .30 & 4.130 & $.000^{*}$ \\
\hline & Erkek & 151 & 8.50 & 3.71 & .30 & & \\
\hline \multirow{2}{*}{ Sosyalleşme } & Kadın & 226 & 10.54 & 4.74 & .29 & 2.604 & $.010^{*}$ \\
\hline & Erkek & 151 & 9.37 & 4.14 & .33 & & \\
\hline \multirow{2}{*}{ Rahatlama } & Kadın & 226 & 10.31 & 4.03 & .26 & 7.907 & $.000^{*}$ \\
\hline & Erkek & 151 & 7.05 & 3.76 & 30 & & \\
\hline
\end{tabular}

*p<.05 Tablo 5. Cinsiyete Göre Bağımsız Gruplar İçin T Testi Sonuçları

Tablo 5'te görüldüğü gibi bireylerin hedonik tüketim değerlerinin tüm alt boyutları arasında cinsiyet değişkenine göre anlamlı bir farklılık görülmektedir. Kadınların alış veriş deneyimlerinde macera, fırsat yakalama, başkalarını mutlu etme, fikir edinme, sosyalleşme ve rahatlama amaçlarının erkeklere oranla daha yüksek olduğu sonucuna ulaşılmıştır.

\subsubsection{Medeni Duruma Göre Hedonik Tüketim Değerleri}

Bireylerin hedonik tüketim değerlerinde medeni durum açısından istatistiksel biçimde anlamlı bir farklılık gösterip göstermediğini tespit etmek için tek yönlü varyans analizi (ANOVA) uygulanmıştır. Bireylere dair aritmetik ortalama ve standart sapma değerlerine Tablo 6'da, ANOVA testi sonuçkarına ise Tablo 7'de yer verilmiştir.

\begin{tabular}{|c|c|c|c|c|}
\hline & Medeni Durum & $\mathbf{n}$ & $\underline{X}$ & SS \\
\hline \multirow{3}{*}{ Macera } & Evli & 206 & 12.08 & 4.81 \\
\hline & Bekar & 153 & 10.18 & 4.66 \\
\hline & Eşinden ayrı/eși vefat etmiş & 18 & 12.05 & 5.03 \\
\hline \multirow{3}{*}{ Firsat Yakalama } & Evli & 206 & 13.08 & 4.30 \\
\hline & Bekar & 153 & 12.97 & 3.98 \\
\hline & Eşinden ayrı/eși vefat etmiş & 18 & 13.94 & 5.21 \\
\hline \multirow{3}{*}{ Başkalarını Mutlu Etme } & Evli & 206 & 16.02 & 4.51 \\
\hline & Bekar & 153 & 15.54 & 4.10 \\
\hline & Eşinden ayrı/eși vefat etmiş & 18 & 14.94 & 3.70 \\
\hline \multirow{2}{*}{ Fikir Edinme } & Evli & 206 & 10.53 & 4.30 \\
\hline & Bekar & 153 & 8.48 & 4.21 \\
\hline
\end{tabular}


Sinan Öz, Erdem Tatlı, "Kişilik Özellikleri ile Hedonik Tüketim Değerleri Arasındaki İlişki Üzerine Bir İnceleme”, İzlek Akademik Dergi (Izlek Academical Journal), 4 (1), 2021, ss. 16-44.

\begin{tabular}{|l|l|l|l|l|}
\hline \multirow{4}{*}{ Sosyalleşme } & Eşinden ayrı/eşi vefat etmiş & 18 & 7.88 & 3.84 \\
\hline \multirow{4}{*}{ Rahatlama } & Evli & 206 & 10.62 & 4.35 \\
\cline { 2 - 5 } & Bekar & 153 & 9.32 & 4.38 \\
\cline { 2 - 5 } & Eşinden ayrı/eşi vefat etmiş & 18 & 10.27 & 3.86 \\
\hline & Evli & 206 & 9.78 & 4.08 \\
\cline { 2 - 5 } & Bekar & 153 & 7.84 & 4.19 \\
\cline { 2 - 5 } & Eşinden ayrı/eşi vefat etmiş & 18 & 10.11 & 4.21 \\
\hline
\end{tabular}

Tablo 6. Medeni Duruma Göre Aritmetik Ortalama Ve Standart Sapma Değerleri

\begin{tabular}{|c|c|c|c|c|c|c|c|}
\hline & $\begin{array}{l}\text { Varyansın } \\
\text { Kaynağı }\end{array}$ & $\begin{array}{l}\text { Kareler } \\
\text { Toplamı }\end{array}$ & Sd & $\begin{array}{l}\text { Kareler } \\
\text { Ortalaması }\end{array}$ & $\mathbf{F}$ & $\mathbf{p}$ & Fark \\
\hline \multirow{3}{*}{ Macera } & Gruplar Arası & 328.819 & 2 & 164.409 & 7.232 & $.001^{*}$ & $1>2$ \\
\hline & Gruplar İçi & 8502.247 & 374 & 22.733 & & & \\
\hline & Toplam & 8831.066 & 376 & & & & \\
\hline \multirow{3}{*}{ Firsat Yakalama } & Gruplar Arası & 15.184 & 2 & 7.592 & 425 & .654 & - \\
\hline & Gruplar İçi & 6673.267 & 374 & 17.843 & & & \\
\hline & Toplam & 6688.451 & 376 & & & & \\
\hline \multirow{3}{*}{$\begin{array}{l}\text { Başkalarını } \\
\text { Mutlu Etme }\end{array}$} & Gruplar Arası & 33.021 & 2 & 16.511 & .884 & .414 & - \\
\hline & Gruplar İçi & 6981.705 & 374 & 18.668 & & & \\
\hline & Toplam & 7014.727 & 376 & & & & \\
\hline \multirow{3}{*}{ Fikir Edinme } & Gruplar Arası & 424.765 & 2 & 212.383 & 11.762 & $.000^{*}$ & $1>2,3$ \\
\hline & Gruplar İçi & 6753.176 & 374 & 18.057 & & & \\
\hline & Toplam & 7177.942 & 376 & & & & \\
\hline \multirow{3}{*}{ Sosyalleşme } & Gruplar Arası & 147,875 & 2 & 73.938 & 3.919 & $.021 *$ & $1>2$ \\
\hline & Gruplar İçi & 7055,737 & 374 & 18.866 & & & \\
\hline & Toplam & 7203,613 & 376 & & & & \\
\hline \multirow{3}{*}{ Rahatlama } & Gruplar Arası & 352,775 & 2 & 176.387 & 10.303 & $.000^{*}$ & $1>2$ \\
\hline & Gruplar İçi & 6403,183 & 374 & 17.121 & & & \\
\hline & Toplam & 6755,958 & 376 & & & & \\
\hline
\end{tabular}

Tablo 7. Medeni Duruma Göre Tek Yönlü Varyans Analizi Sonuçları

Tablo 7'de görüldügü gibi tek yönlü varyans analizi sonucunda macera, fikir edinme, sosyalleşme ve rahatlama puanlarında medeni duruma göre anlamlı bir farklılık olduğu bulunmuştur. Ortaya çıkan farklılığın hangi gruplar arasında olduğunun tespit edilmesi amacıyla Post-Hoc analizlerine geçilmiştir. Pos-Hoc analizlerinden hangisinin kullanılacağının tespit edilmesi adına Levene testi 
uygulanmış ve grup dağılımlarının homojenliği test edilmiştir. Levene testi sonucunda varyansların homojen olduğu tespit edilmiştir. Bu durumda araştırmalarda sıklıkla tercih edilen Tukey Testi kullanılarak karşıllaştırma analizi yapılmıştır. Macera, sosyalleşme ve rahatlama alt boyutları arasındaki farkın evli ve bekar bireyler arasında olduğu görülmüştür. Evli bireylerin, macera, sosyalleşme ve rahatlama amacıyla daha fazla alış veriş deneyimi yaşadıkları sonucuna ulaşılmıştır. Fikir edinme alt boyutuna bakıldığında ise farkın evli bireyler ile bekar ve boşanmış/eşini kaybetmiş bireyler arasında olduğu görülmektedir. Bu alt boyutta da fark evli bireyler lehinedir. Evli bireylerin fikir edinme amacıyla yapmış oldukları alış veriş bekar ve boşanmış/eşini kaybetmiş bireylere oranla daha fazladır.

Bu doğrultuda H3 hipotezinin kabul edildiği görülmektedir.

\subsubsection{Yaşa Göre Hedonik Tüketim Değerleri}

Bireylerin hedonik tüketim değerlerinde yaş açısından istatistiksel biçimde anlamlı bir farklılık gösterip göstermediğini tespit etmek için tek yönlü varyans analizi (ANOVA) uygulanmıştır. Bireylere dair aritmetik ortalama ve standart sapma değerlerine Tablo 8'de, ANOVA testi sonuçkarına ise Tablo 9'da yer verilmiştir.

\begin{tabular}{|c|c|c|c|c|}
\hline & Yaş & $\mathbf{n}$ & $\underline{X}$ & SS \\
\hline \multirow{4}{*}{ Macera } & $18-25$ & 100 & 12.19 & 4.87 \\
\hline & $26-35$ & 136 & 11.60 & 4.70 \\
\hline & $36-45$ & 91 & 10.42 & 4.93 \\
\hline & 46 ve üzeri & 50 & 10.38 & 4.73 \\
\hline \multirow{4}{*}{ Firsat Yakalama } & $18-25$ & 100 & 13.32 & 4.42 \\
\hline & $26-35$ & 136 & 12.94 & 4.37 \\
\hline & $36-45$ & 91 & 12.97 & 3.89 \\
\hline & 46 ve üzeri & 50 & 13.16 & 4.29 \\
\hline \multirow{4}{*}{ Başkalarını Mutlu Etme } & $18-25$ & 100 & 16.67 & 4.24 \\
\hline & $26-35$ & 136 & 15.44 & 4.44 \\
\hline & $36-45$ & 91 & 16.01 & 4.28 \\
\hline & 46 ve üzeri & 50 & 14.50 & 3.85 \\
\hline \multirow{4}{*}{ Fikir Edinme } & $18-25$ & 100 & 10.90 & 4.19 \\
\hline & $26-35$ & 136 & 9.89 & 4.48 \\
\hline & $36-45$ & 91 & 8.25 & 4.10 \\
\hline & 46 ve üzeri & 50 & 8.48 & 4.04 \\
\hline \multirow{4}{*}{ Sosyalleşme } & $18-25$ & 100 & 11.40 & 4.32 \\
\hline & 26-35 & 136 & 10.05 & 4.12 \\
\hline & $36-45$ & 91 & 8.90 & 4.25 \\
\hline & 46 ve üzeri & 50 & 9.64 & 4.76 \\
\hline \multirow{4}{*}{ Rahatlama } & $18-25$ & 100 & 9.81 & 4.04 \\
\hline & 26-35 & 136 & 9.44 & 4.22 \\
\hline & $36-45$ & 91 & 7.97 & 4.06 \\
\hline & 46 ve üzeri & 50 & 8.12 & 4.54 \\
\hline
\end{tabular}

Tablo 8. Yaşa Göre Aritmetik Ortalama Ve Standart Sapma Değerleri 
Sinan Öz, Erdem Tatlı, "Kișilik Özellikleri ile Hedonik Tüketim Değerleri Arasındaki İlișki Üzerine Bir İnceleme”, İzlek Akademik Dergi (Izlek Academical Journal), 4 (1), 2021, ss. 16-44.

\begin{tabular}{|c|c|c|c|c|c|c|c|}
\hline & $\begin{array}{l}\text { Varyansın } \\
\text { Kaynağı }\end{array}$ & $\begin{array}{l}\text { Kareler } \\
\text { Toplamı }\end{array}$ & Sd & $\begin{array}{l}\text { Kareler } \\
\text { Ortalaması }\end{array}$ & $\mathbf{F}$ & $\mathbf{p}$ & Fark \\
\hline \multirow{3}{*}{ Macera } & Gruplar Arası & 203.052 & 3 & 67.684 & 2.926 & $.034^{*}$ & $1>3$ \\
\hline & Gruplar İçi & 8628.015 & 373 & 23.131 & & & \\
\hline & Toplam & 8831.066 & 376 & & & & \\
\hline \multirow{3}{*}{ Firsat Yakalama } & Gruplar Arası & 9.375 & 3 & 3.125 & .175 & .914 & - \\
\hline & Gruplar İçi & 6679.076 & 373 & 17.906 & & & \\
\hline & Toplam & 6688.451 & 376 & & & & \\
\hline \multirow{3}{*}{$\begin{array}{l}\text { Başkalarını Mutlu } \\
\text { Etme }\end{array}$} & Gruplar Arası & 181.598 & 3 & 60.533 & 3.304 & $.020^{*}$ & $1>4$ \\
\hline & Gruplar İçi & 6833.128 & 373 & 18.319 & & & \\
\hline & Toplam & 7014.727 & 376 & & & & \\
\hline \multirow{3}{*}{ Fikir Edinme } & Gruplar Arası & 408.716 & 3 & 136.239 & 7.507 & $.000^{*}$ & $1>3,4$ \\
\hline & Gruplar İçi & 6769.226 & 373 & 18.148 & & & $2>4$ \\
\hline & Toplam & 7177.942 & 376 & & & & \\
\hline \multirow{3}{*}{ Sosyalleşme } & Gruplar Arası & 310.453 & 3 & 103.484 & 5.600 & $.001^{*}$ & $1>3$ \\
\hline & Gruplar İçi & 6893.159 & 373 & 18.480 & & & \\
\hline & Toplam & 7203.613 & 376 & & & & \\
\hline \multirow{3}{*}{ Rahatlama } & Gruplar Arası & 225.802 & 3 & 75.267 & 4.299 & $.005^{*}$ & $1,2>3$ \\
\hline & Gruplar İçi & 6530.155 & 373 & 17.507 & & & \\
\hline & Toplam & 6755.958 & 376 & & & & \\
\hline
\end{tabular}

${ }^{*} \mathrm{p}<.05 \quad$ Tablo 9. Yaşa Göre Tek Yönlü Varyans Analizi Sonuçları

Tablo 9'da görüldüğü gibi tek yönlü varyans analizi sonucunda macera, başkalarını mutlu etme, fikir edinme, sosyalleşme ve rahatlama puanlarında yaşa göre anlamlı bir farklılık olduğu bulunmuştur. Ortaya çıkan farklılığın hangi gruplar arasında olduğunun tespit edilmesi amacıyla Post-Hoc analizlerine geçilmiştir. Pos-Hoc analizlerinden hangisinin kullanılacağının tespit edilmesi adına Levene testi uygulanmış ve grup dağılımlarının homojenliği test edilmiştir. Levene testi sonucunda varyansların homojen olduğu tespit edilmiştir. Bu durumda araştırmalarda sıklıkla tercih edilen Tukey Testi kullanılarak karşılaştırma analizi yapılmıştır. Macera ve sosyalleşme alt boyutları arasındaki farkın 18-25 yaş aralığında bulunan bireyler ile 36-45 yaş aralığındakiler arasında olduğu görülmüştür. 18-25 yaş aralığında bulunan bireylerin macera ve sosyalleşme amacıyla daha fazla alış veriş deneyimi yaşadıkları sonucuna ulaşılmıştır. Başkalarını mutlu etme alt boyutundaki farkın ise 18-25 yaş aralığında bulunan bireyler ile 46 yaş ve üzerinde olanlar arasında olduğu, 18-25 yaş aralığındaki bireylerin başkalarını mutlu etme amacıyla daha fazla alış veriş deneyimi yaşadıkları sonucuna ulaşılmıştır. Fikir edinme alt boyutunda ise farkın 18-25 yaş aralığındaki bireyler ile 36-45 yaş aralığında ve 46 yaş ve üzerinde olanlar; 26-35 yaş aralığındaki bireyler ile 46 yaş ve üzerinde olanlar arasında olduğu görülmektedir. 18-25 yaş aralığında bulunan bireylerin ile 36-45 yaş aralığında ve 46 yaş ve üzerinde olanlara oranla fikir edinme amacıyla daha fazla alış veriş deneyimi yaşadıkları sonucuna ulaşılmıştır. Bununla birlikte 26-35 yaş aralığında bulunan bireylerin 46 yaș ve üzerinde olanlara oranla fikir edinme amacıyla 
daha fazla alış veriş deneyimi yaşadıkları sonucuna ulaşılmıştır. Son olarak rahatlama alt boyutuna bakıldığında ise farkın 18-25 yaş aralığında bulunanlar ve 26-35 yaş aralığında bulunanlar ile 36-45 yaş aralığındaki bireyler arasında olduğu görülmektedir. 18-25 ve 26-35 yaş aralığında bulunan bireyler, 36-45 yaş aralığındaki bireylere oranla rahatlama amacıyla daha fazla alış veriş deneyimi yaşadıkları sonucuna ulaşılmıştır.

Bu doğrultuda H4 hipotezinin kabul edildiği görülmektedir.

\subsubsection{Gelir Düzeyine Göre Hedonik Tüketim Değerleri}

Bireylerin hedonik tüketim değerlerinde gelir düzeyi açısından istatistiksel biçimde anlamlı bir farklılık gösterip göstermediğini tespit etmek için tek yönlü varyans analizi (ANOVA) uygulanmıştır. Bireylere dair aritmetik ortalama ve standart sapma değerlerine Tablo 10'da, ANOVA testi sonuçkarına ise Tablo 11'de yer verilmiştir.

\begin{tabular}{|c|c|c|c|c|}
\hline & Gelir Düzeyi & $\mathbf{n}$ & $\underline{X}$ & SS \\
\hline \multirow{3}{*}{ Macera } & 2500 TL ve altı & 95 & 11.56 & 4.86 \\
\hline & $2501-5000 \mathrm{TL}$ & 129 & 11.45 & 5.12 \\
\hline & 5000 TL ve üzeri & 153 & 11.03 & 4.61 \\
\hline \multirow{3}{*}{ Firsat Yakalama } & 2500 TL ve altı & 95 & 13.61 & 4.39 \\
\hline & $2501-5000 \mathrm{TL}$ & 129 & 13.21 & 4.36 \\
\hline & 5000 TL ve üzeri & 153 & 12.64 & 3.94 \\
\hline \multirow{3}{*}{ Başkalarını Mutlu Etme } & 2500 TL ve altı & 95 & 15.40 & 4.58 \\
\hline & $2501-5000 \mathrm{TL}$ & 129 & 16.24 & 4.30 \\
\hline & 5000 TL ve üzeri & 153 & 15.62 & 4.14 \\
\hline \multirow{3}{*}{ Fikir Edinme } & 2500 TL ve altı & 95 & 9.74 & 3.98 \\
\hline & $2501-5000 \mathrm{TL}$ & 129 & 9.79 & 4.67 \\
\hline & 5000 TL ve üzeri & 153 & 9.29 & 4.34 \\
\hline \multirow{3}{*}{ Sosyalleşme } & 2500 TL ve altı & 95 & 10.51 & 4.31 \\
\hline & $2501-5000 \mathrm{TL}$ & 129 & 10.21 & 4.54 \\
\hline & 5000 TL ve üzeri & 153 & 9.69 & 4.26 \\
\hline \multirow{3}{*}{ Rahatlama } & 2500 TL ve altı & 95 & 9.20 & 3.94 \\
\hline & $2501-5000 \mathrm{TL}$ & 129 & 9.33 & 4.38 \\
\hline & 5000 TL ve üzeri & 153 & 8.62 & 4.28 \\
\hline
\end{tabular}

Tablo 10. Gelir Düzeyine Göre Tek Yönlü Varyans Analizi Sonuçları 
Sinan Öz, Erdem Tatlı, "Kişilik Özellikleri ile Hedonik Tüketim Değerleri Arasındaki İlişki Üzerine Bir İnceleme”, İzlek Akademik Dergi (Izlek Academical Journal), 4 (1), 2021, ss. 16-44.

\begin{tabular}{|c|c|c|c|c|c|c|c|}
\hline & $\begin{array}{l}\text { Varyansın } \\
\text { Kaynağı }\end{array}$ & $\begin{array}{l}\text { Kareler } \\
\text { Toplamı }\end{array}$ & Sd & $\begin{array}{l}\text { Kareler } \\
\text { Ortalaması }\end{array}$ & $\mathbf{F}$ & $\mathbf{p}$ & Fark \\
\hline \multirow{3}{*}{ Macera } & Gruplar Arası & 20.909 & 2 & 10.454 & .444 & .642 & - \\
\hline & Gruplar İçi & 8810.157 & 374 & 23.557 & & & \\
\hline & Toplam & 8831.066 & 376 & & & & \\
\hline \multirow{3}{*}{ Firsat Yakalama } & Gruplar Arası & 58.710 & 2 & 29.355 & 1.656 & .192 & - \\
\hline & Gruplar İçi & 6629.741 & 374 & 17.727 & & & \\
\hline & Toplam & 6688.451 & 376 & & & & \\
\hline \multirow{3}{*}{$\begin{array}{l}\text { Başkalarını Mutlu } \\
\text { Etme }\end{array}$} & Gruplar Arası & 44.612 & 2 & 22.306 & 1.197 & .303 & - \\
\hline & Gruplar İçi & 6970.115 & 374 & 18.637 & & & \\
\hline & Toplam & 7014.727 & 376 & & & & \\
\hline \multirow{3}{*}{ Fikir Edinme } & Gruplar Arası & 20.891 & 2 & 10.446 & .546 & .580 & - \\
\hline & Gruplar İçi & 7157.050 & 374 & 19.136 & & & \\
\hline & Toplam & 7177.942 & 376 & & & & \\
\hline \multirow{3}{*}{ Sosyalleşme } & Gruplar Arası & 43.402 & 2 & 21.701 & 1.134 & .323 & - \\
\hline & Gruplar İçi & 7160.211 & 374 & 19.145 & & & \\
\hline & Toplam & 7203.613 & 376 & & & & \\
\hline \multirow{3}{*}{ Rahatlama } & Gruplar Arası & 40.078 & 2 & 20.039 & 1.116 & .329 & - \\
\hline & Gruplar İçi & 6715.880 & 374 & 17.957 & & & \\
\hline & Toplam & 6755.958 & 376 & & & & \\
\hline
\end{tabular}

Tablo 11. Gelir Düzeyine Göre Tek Yönlü Varyans Analizi Sonuçları

Tablo 11'de görüldügü gibi tek yönlü varyans analizi sonucunda bireylerin hedonik tüketim değerlerinde tüm alt boyutların gelir düzeyi değişkenine göre anlamlı bir farklılık göstermediği bulunmuştur.

Bu doğrultuda H5 hipotezinin reddedildiği görülmektedir.

\subsubsection{5. ～～Eğitim Düzeyine Göre Hedonik Tüketim Değerleri}

Bireylerin hedonik tüketim değerlerinde eğitim düzeyi açısından istatistiksel biçimde anlamlı bir farklılık gösterip göstermediğini tespit etmek için tek yönlü varyans analizi (ANOVA) uygulanmıştır. Bireylere dair aritmetik ortalama ve standart sapma değerlerine Tablo 12'de, ANOVA testi sonuçkarına ise Tablo 13'te yer verilmiştir. 
Sinan Öz, Erdem Tatlı, “Kişilik Özellikleri ile Hedonik Tüketim Değerleri Arasındaki İlișki Üzerine Bir İnceleme”, İzlek Akademik Dergi (Izlek Academical Journal), 4 (1), 2021, ss. 16-44.

\begin{tabular}{|c|c|c|c|c|}
\hline & Eğitim Düzeyi & $\mathbf{n}$ & $\underline{X}$ & SS \\
\hline \multirow{4}{*}{ Macera } & Lise & 95 & 11.43 & 5.09 \\
\hline & Ön Lisans & 40 & 12.20 & 4.97 \\
\hline & Lisans & 176 & 11.28 & 4.86 \\
\hline & Lisansüstü & 66 & 10.66 & 4.34 \\
\hline \multirow{4}{*}{ Firsat Yakalama } & Lise & 95 & 12.88 & 4.30 \\
\hline & Ön Lisans & 40 & 12.75 & 4.76 \\
\hline & Lisans & 176 & 13.17 & 4.23 \\
\hline & Lisansüstü & 66 & 13.33 & 3.73 \\
\hline \multirow{4}{*}{ Başkalarını Mutlu Etme } & Lise & 95 & 15.63 & 4.63 \\
\hline & Ön Lisans & 40 & 16.35 & 4.43 \\
\hline & Lisans & 176 & 15.66 & 4.33 \\
\hline & Lisansüstü & 66 & 15.95 & 3.76 \\
\hline \multirow{4}{*}{ Fikir Edinme } & Lise & 95 & 9.41 & 4.17 \\
\hline & Ön Lisans & 40 & 10.37 & 4.45 \\
\hline & Lisans & 176 & 9.57 & 4.55 \\
\hline & Lisansüstü & 66 & 9.34 & 4.13 \\
\hline \multirow{4}{*}{ Sosyalleşme } & Lise & 95 & 10.11 & 4.47 \\
\hline & Ön Lisans & 40 & 10.80 & 3.98 \\
\hline & Lisans & 176 & 10.14 & 4.57 \\
\hline & Lisansüstü & 66 & 9.40 & 3.91 \\
\hline \multirow{4}{*}{ Rahatlama } & Lise & 95 & 8.76 & 4.37 \\
\hline & Ön Lisans & 40 & 9.80 & 3.97 \\
\hline & Lisans & 176 & 9.32 & 4.31 \\
\hline & Lisansüstü & 66 & 8.04 & 3.88 \\
\hline
\end{tabular}

Tablo 12. Eğitim Düzeyine Göre Tek Yönlü Varyans Analizi Sonuçları 
Sinan Öz, Erdem Tatlı, "Kişilik Özellikleri ile Hedonik Tüketim Değerleri Arasındaki İlişki Üzerine Bir İnceleme”, İzlek Akademik Dergi (Izlek Academical Journal), 4 (1), 2021, ss. 16-44.

\begin{tabular}{|c|c|c|c|c|c|c|c|}
\hline & $\begin{array}{l}\text { Varyansın } \\
\text { Kaynağı }\end{array}$ & $\begin{array}{l}\text { Kareler } \\
\text { Toplamı }\end{array}$ & Sd & $\begin{array}{l}\text { Kareler } \\
\text { Ortalaması }\end{array}$ & $\mathbf{F}$ & $\mathbf{p}$ & Fark \\
\hline \multirow{3}{*}{ Macera } & Gruplar Arası & 60.473 & 3 & 20.158 & .857 & .463 & - \\
\hline & Gruplar İçi & 8770.594 & 373 & 23.514 & & & \\
\hline & Toplam & 8831.066 & 376 & & & & \\
\hline \multirow{3}{*}{ Firsat Yakalama } & Gruplar Arası & 13.672 & 3 & 4.557 & .255 & .858 & - \\
\hline & Gruplar İçi & 6674.779 & 373 & 17.895 & & & \\
\hline & Toplam & 6688.451 & 376 & & & & \\
\hline \multirow{3}{*}{$\begin{array}{l}\text { Başkalarını Mutlu } \\
\text { Etme }\end{array}$} & Gruplar Arası & 19.436 & 3 & 6.479 & .345 & .792 & - \\
\hline & Gruplar İçi & 6995.290 & 373 & 18.754 & & & \\
\hline & Toplam & 7014.727 & 376 & & & & \\
\hline \multirow{3}{*}{ Fikir Edinme } & Gruplar Arası & 31.553 & 3 & 10.518 & .549 & .649 & - \\
\hline & Gruplar İçi & 7146.389 & 373 & 19.159 & & & \\
\hline & Toplam & 7177.942 & 376 & & & & \\
\hline \multirow{3}{*}{ Sosyalleşme } & Gruplar Arası & 51.373 & 3 & 17.124 & .893 & .445 & - \\
\hline & Gruplar İçi & 7152.240 & 373 & 19.175 & & & \\
\hline & Toplam & 7203.613 & 376 & & & & \\
\hline \multirow{3}{*}{ Rahatlama } & Gruplar Arası & 109.249 & 3 & 36.416 & 2.044 & .107 & - \\
\hline & Gruplar İçi & 6646.709 & 373 & 17.820 & & & \\
\hline & Toplam & 6755.958 & 376 & & & & \\
\hline
\end{tabular}

*p<.05 Tablo 13. Eğitim Düzeyine Göre Tek Yönlü Varyans Analizi Sonuçları

Tablo 13'te görüldüğg̈ gibi tek yönlü varyans analizi sonucunda bireylerin hedonik tüketim değerlerinde tüm alt boyutların eğitim düzeyi değișkenine göre anlamlı bir farklılık göstermediği bulunmuştur.

Bu doğrultuda H6 hipotezinin reddedildiği görülmektedir.

\section{Sonuç ve Değerlendirme}

Bireylerin satın alma eylemlerinde duygusal açıdan tatmin olmayı arzuladığı alışveriş biçimi "hedonik tüketim" olarak ifade edilmektedir. Bu araştırmada, kişilik özelliklerinin hedonik tüketim değerleri ile olan ilişkisi araştırılmıştır. Bu doğrultuda ilk olarak kişilik özelliklerini ve hedonik tüketim nedenlerini belirlemek amacıyla kullanılacak olan ölçme araçları belirlenmiş ve ölçme araçlarının geliştirici veya uyarlayıcılarından izin alınmıştır. Veri toplama araçları için gerekli izinlerin alınmasının ardından veri seti bir araya getirilmiştir. Veri setinin ilk bölümü araştırmaya katılan bireylerin demografik özelliklerini belirmek adına bireylere yöneltilen sorulardan, ikinci bölümü hedonik tüketim nedenlerini belirlemeye yönelik 23 sorudan, üçüncü bölüm ise kişilik özelliklerini belirlemeye yönelik 40 sorudan oluşmaktadır. Araştırma evreni İstanbul'da yaşayan 18 yaşından büyük, en az lise mezunu bireylerden oluşmaktadır. Araştırmaya toplam 382 kişi katılım göstermiştir. Veriler 2021 yılının Ocak ayında toplanmıştır. Ölçme 
araçlarından elde edilen verilere çeşitli istatistiksel analizler uygulanmış ve sonuçlar yorumlanmıştır.

Araştırmaya katılan bireylerin demografik özelliklerine bakıldığında katılımcıların \%60.5'in kadın olduğu, \%54.3'ünün evli olduğu, 26-35 yaş aralığının en fazla aralık olduğu (\%35.9), gelir düzeyinin en fazla 5000 TL ve üzeri (\%40.3) olduğu, eğitim düzeyinin ise en fazla lisans (\%46.3) düzeyinde olduğu görülmüştür.

Hedonik tüketim değerleri ile kişilik özellikleri arasındaki ilişkiyi belirlemek amacıyla Pearson Momentler Çarpımı Korelasyon Analizi yapılmıştır. Korelasyon analizi sonucunda, dışadönüklük kişilik özelliği ile macera yaşama, fırsat yakalama, başkalarını mutlu etme, fikir edinme, sosyalleşme ve rahatlama arasında pozitif yönde anlamlı bir ilişki olduğu görülmüştür. Hedonik tüketim ve kişilik özellikleri arasındaki ilişkinin incelendiği çalışmalara bakıldığında Solunoğlu ve İkiz (2020) tarafından yapılan araştırmada, dışadönük kişilik özelliğine sahip olan bireylerin başkalarını mutlu etme, fikir edinme ve macera amaçlı alışveriş yapma davranışlarının daha yoğun olduğu ortaya koyulmuştur.

Bununla birlikte uyumluluk kişilik özelliği ile başkalarını mutlu etme ve sosyalleşme hedonik tüketim değeri arasında pozitif yönde anlamlı bir ilişkinin olduğu görülmüştür. Benzer şekilde Solunoğlu ve İkiz (2020) de başkalarını mutlu etme amaçlı alışveriş ile uyumluluk kişilik özelliği arasında pozitif yönde anlamlı bir ilişki bulunduğunu belirtmektedir. Aynı zamanda Guido (2006) tarafından yapılan araştırmada kişilik özellikleri ile faydacı alışveriş arasındaki ilişkinin incelenmesi amaçlanmıştır. Araştırma sonucunda dışadönük, uyumlu ve deneyime açık kişilik özelliklerinin hedonik tüketim ile bağlantılı olduğu belirtilmiştir. Bir diğer araştırmada ise dışadönük, uyumlu, deneyime açık ve sorumlu kişilik özelliklerinin bulunduğu bireylerin, alış veriş anlamında daha yetkin oldukları ortaya koyulmuştur (Flynn ve Goldsmith, 2015).

Sorumluluk kişilik özelliği ile macera yaşama, başkalarını mutlu etme ve sosyalleşme hedonik tüketim değerleri arasında pozitif yönde anlamlı bir ilişkinin olduğu görülmüştür. Bununla birlikte duygusal dengesizlik kişilik özelliği ile macera yaşama, firsat yakalama, fikir edinme, sosyalleşme ve rahatlama hedonik tüketim değerleri arasında pozitif yönde anlamlı bir ilişkinin olduğu görülmüștür.

Deneyime açıklık kişilik özelliği ile başkalarını mutlu etme ve sosyalleşme hedonik tüketim değerleri arasında pozitif yönde anlamlı bir ilişkinin olduğu görülmüştür. Goldsmith (2015) tarafından yapılan araştırmada deneyime açıklık kişilik özelliğinin alış veriş üzerinde temel bir etkisinin olduğu ortaya koyulmuştur. Solunoğlu ve İkiz (2020) tarafından yapılan araştırmada ise deneyime açık kişilik özelliği ile fikir amaçlı alışveriş boyutu dışındaki tüm hedonik alışveriş alt boyutlarının ilişkili olduğu sonucuna ulaşılmıştır.

Demografik özelliklere göre, hedonik tüketim değerlerinin incelenmesinde cinsiyete göre bağımsız gruplar için t-testi analizi, diğer değişkenlere göre (medeni durum, yaş, gelir düzeyi ve eğitim düzeyi) tek yönlü varyans analizi (ANOVA) kullanılmıştır.

Macera yaşama, fırsat yakalama, başkalarını mutlu etme, fikir edinme, sosyalleşme ve rahatlama hedonik tüketim değerlerinin cinsiyet değișkenine göre anlamlı olarak farklılaştığı; kadınların macera yaşama, fırsat yakalama, başkalarını mutlu etme, fikir edinme, sosyalleşme ve rahatlama amaçlı hedonik tüketimlerinin erkeklere oranla daha yüksek olduğu görülmüştür. İlgili literatür incelendiğinde cinsiyet ve hedonik tüketim değerleri arasındaki farklılığın incelendiği çalışmalarda farklı bulguların elde edildiği görülmektedir. Kusuma ve ark. (2012) tarafından 
yapılan araştırmada kadınların hedonik tüketim davranışlarında daha etkili olduğu görülmüştür. Benzer şekilde Özgül (2011) tarafından yapılan araştırmada da kadınların daha yüksek puan aldıkları görülmüştür. Bu sonu. Araştırma bulguları ile tutarlılık göstermektedir. Ancak Altan (2019) tarafından yapılan araştırmada tam tersi olarak erkeklerin daha yüksek puanlara sahip olduğu görülmüştür. Görüldüğü gibi bulgular farklılık göstermektedir. Bu konuda daha fazla ihtiyaç duyulduğu görülmektedir.

Macera yaşama, fikir edinme, sosyalleşme ve rahatlama hedonik tüketim değerlerinin medeni durum değişkenine göre anlamlı olarak farklılaştı̆̆ı; evli bireylerin macera, sosyalleşme ve rahatlama amaçlı hedonik tüketimlerinin bekarlara oranla daha yüksek olduğu görülmüştür. Bununla birlikte evli bireylerin fikir edinme amaçlı hedonik tüketimlerinin bekar ve boşanmış/eşini kaybetmiş bireylere oranla daha yüksek olduğu görülmüştür. Araștırma bulgularından farklı olarak Altan (2019) tarafından yapılan araştırmada, medeni durum ve hedonik tüketim değerleri arasında anlamlı bir farklılık olmadığı görülmüştür. Özkan (2017) ve Özgül (2011) tarafından yapılan araştırmada ise evli bireylerin rahatlama amacıyla alış veriş yapma puanlarının daha yüksek olduğu sonucuna ulaşılmıştır.

Macera yaşama, başkalarını mutlu etme, fikir edinme, sosyalleşme ve rahatlama hedonik tüketim değerlerinin yaş değişkenine göre anlamlı olarak farklılaştığı; 18-25 yaş aralığında bulunan bireylerin macera yaşama amaçlı ve sosyalleşme amaçlı hedonik tüketimlerinin 36-45 yaş aralığındakilere oranla daha yüksek olduğu görülmüştür. Bununla birlikte 18-25 yaş aralığında bulunan bireylerin başkalarını mutlu etme amaçlı hedonik tüketimlerinin 46 yaș ve üzerindekilere oranla daha yüksek olduğu görülmüştür. 18-25 yaş aralığında bulunan bireylerin fikir edinme amaçlı hedonik tüketimlerinin $36-45$ yaş ve 46 yaş ve üzerindekilere oranla; 26-35 yaş aralığında bulunan bireylerin ise 46 yaş ve üzerindekilere oranla daha yüksek olduğu görülmüştür. Son olarak 18-25 ve 26-35 yaş aralığında bulunan bireylerin rahatlama amaçlı hedonik tüketimlerinin 36-45 yaş aralığında bulunan bireylere oranla daha yüksek olduğu görülmüştür. Özgül (2011) tarafından yapılan araştırmada orta ve üstü yaş grubundaki bireylerin hedonik tüketimlerinin daha yüksek olduğu sonucuna ulaşılmıştır.

Bireylerin hedonik tüketim değerlerinin gelir düzeyi ve eğitim düzeyi değişkenleri açısından anlamlı olarak farklılaşmadığı bulunmuştur. Özgül (2011) tarafından yapılan araştırmada ise bu araştırmanın bulgularından farklı olarak gelir düzeyi ve eğitim düzeyi daha düşük olan bireylerin hedonik tüketim puanlarının daha yüksek olduğu ortaya koyulmuştur.

Bir ürünün satışında başarılı olunması, farklı faktörlerin etkisi bulunmaktadır. Bu faktörlerden en önemlisi ise hedef kitlenin tanınması olarak kabul edilmektedir (Yllmaz, 2016). Hedef kitle "verilmek istenen mesajın ulaşılması beklenen topluluk veya grup" olarak tanımlanmaktadır (TDK, 2021). Piyasadaki rekabetin her geçen gün arttığı gözle görülür bir gerçektir. Bu noktada hedef kitlesini doğru analiz etmiş ve belirlemiş satıcıların diğerlerine oranla önde olacakları düşünülmektedir. Hedef kitle, ürün satışındaki pazarlama iletişiminin en temel unsudur ve tüm harcanan efor bu doğrultuda yönlendirilmektedir. Bu doğrultuda hedef kitle, "gerçekleștirilen tüm etkinlik ve işlemerin yönlendirildiği, bunlar neticesinde kendilerinden düşünce ve davranış değişimi hedeflenen bireyler veya gruplar" şeklinde tanımlanabilmektedir (Yılmaz, 2016). Hedef kitle, farklı iletişim kanalları aracılı̆̆ıyla kendisine gelen bilgileri, oluşturmuş olduğu ön eğilimleri ile algllar ve değerlendirmesini gerçekleştirir. Bu doğrultuda pazarlama sürecinde, öncelikle hedef kitlenin ön eğilimlerinin, hedef kitle üzerinde etkisi bulunan kişisel ya da çevresel unsurların, hedef kitleyi meydana getiren bireylerin demografik özelliklerinin ve satın alma modellerinin incelenmesi önemli bir süreç haline gelmektedir. 
Bu noktada, satın alma davranışına neden olan tüketicilerin kişilik özellikleri ve kişilik yapılarının incelenmesi oldukça önemlilik arz etmektedir. Demografik, sosyal, durumsal ve kültürel unsurlar ile meydana gelen tüketici davranışları bir noktada satın alma davranışının sebeplerini de açılamaktadır. İşletmeler bu alanda, müşterilerinin satın alma sebeplerini ortaya koyma adına müşterilerinin beklentilerini iyi analiz etmeli ve kendisine gelen müşteri kitlesinin farkında olarak satın alma stratejilerini geliştirmelilerdir.

$\mathrm{Bu}$ araştırmada genel alanda hedonik tüketim davranışları incelenmiştir. Herhangi bir özel alan, marka veya sektör sınırlandırması yapılmamıştır. Gelecek araştırmalarda spesifik bir alan, marka veya sektör seçilerek derinlemesine bir araştırma gerçekleștirilebilir.

Araștırma yalnızca İstanbul ilinde bulunan bir alış veriş merkezine gelen ve en az lise mezunu olan bireyler dahil edilerek gerçekleştirilmiştir. Araştırma farklı örneklem grupları ile gerçekleștirilerek kapsayıcılığı ve genellenebilirliği arttırılabilir.

\section{Kaynakça}

ALKAN, G. (2014). Kişilik Özelliklerinin Örgütsel Stres Üzerine İlişkisi (Antalya Atatürk Devlet Hastanesi) Hemşireleri Üzerine Bir Çalışma (Yayımlanmamış Yüksek Lisans Tezi). Beykent Üniversitesi, İstanbul.

ARNOLD, M. J., \& REYNOLDS, K. E. (2003). Hedonic shopping motivations. Journal of retailing, 79(2), 77-95.

ASLAN, S. (2008). Kişilik, huy ve psikopatoloji. Rewiews, Cases and Hypotheses in Psychiatry RCHP, 2(1-2), 7-18.

AYTEKIN, P., \& AY, C. (2015). Hedonik Tüketim Ve Anlik Satin Alma: İzmir İlinde Bir Araştirma. Niğde Üniversitesi İktisadi ve İdari Bilimler Fakültesi Dergisi, 8(1), 141-156.

BABACAN, M. (2001). Hedonik tüketim ve özel günler alışverişlerine yansıması. 6. Ulusal Pazarlama Kongresi, 28, 97-106.

BACANLI, H., İLHAN, T. ve ASLAN, S. (2009). Beş faktör kuramina dayali bir kişilik ölçeğinin geliştirilmesi: sifatlara dayali kişilik testi (SDKT). Türk Ĕgitim Bilimleri Dergisi, 7(2), 261-279.

BAUDRILLARD, J. (2004). Tüketim Toplumu (Çev. Hazal Deliçaylı-Ferda Keskin). İstanbul: Sarmal Yayınları.

BÜYÜKÖZTÜRK, Ş. (2011). Sosyal bilimler için veri analizi el kitabı. Ankara: Pegem Akademi.

BÜYÜKÖZTÜRK, S., KILIÇ ÇAKMAK, E., AKGÜN, Ö. E., Karadeniz, S. ve Demirel, F. (2012). Bilimsel arastirma yöntemleri. Ankara: Pegem Akademi Yayimcilik.

CAN, A. (2017). SPSS ile bilimsel araştırma sürecinde nicel veri analizi. Ankara: Pegem Akademi.

CERVONE, D. ve PERVIN, L. A. (2016). Kişilik psikolojisi kuram ve araştırma. M. Baloğlu (Ed.), Kişilik kuramı: günlük gözlemlerden sistematik kuramlara (Çev. M. Baloğlu) içinde (s. 8-9). Ankara: Nobel Yayıncılık.

CEYLAN, C. (2007). Hedonik Tüketimin Nedenleri Üzerine Bir Araştırma (Yayımlanmamış Yüksek Lisans Tezi). Atatürk Üniversitesi Sosyal Bilimler Enstitüsü, Erzurum. 
CHANG, H. J., ECKMAN, M., \& YAN, R. N. (2011). Application of the Stimulus-Organism-Response model to the retail environment: the role of hedonic motivation in impulse buying behavior. The International Review of Retail, Distribution and Consumer Research, 21(3), 233-249.

COŞKUN, S (2011). Küreselleşme Sürecinde Tüketim Toplumu ve Tüketim kültürü (Yayımlanmamış Yüksek Lisans Tezi). Necmettin Erbakan Üniversitesi, Konya.

ÇAKIR, İ. (2000). Kişilik Tiplerinin Takım Performansına Etkisi (Yayımlanmamış Yüksek Lisans Tezi). Anadolu Üniversitesi, Eskişehir.

ÇELIK, S. (2009). Hazsal ve Faydacı Tüketim. İstanbul: Derin Yayınları.

ÇETIN, N.G. ve BECEREN, E. (2007), Lider Kişilik: Gandhi. Süleyman Demirel Üniversitesi Sosyal Bilimler Enstitüsü Dergisi, 3(5), 110-132.

ÇOKLUK, Ö., ŞEKERCIOĞLU, G., ve Büyüköztürk, Ș. (2012). Sosyal bilimler için çok değişkenli istatistik: SPSS ve LISREL uygulamaları. Ankara: Pegem Akademi.

DOĞAN, H. G., GÜRLER, A. Z., ve AĞCADAĞ, D. (2014). Hedonik Tüketim Alışkanlıkları Üzerine Etkili Faktörlerin Değerlendirilmesi (Tokat İli Örneği). Journal Of International Social Research, 7(30), 70-77.

EBRAHIMİ, F. (2013). Moda Üzerinde Hedonik Tüketim ve İçgüdüsel Alıșverișin Etkileri Konusunda Bir Alan Araştırması (Yayımlanmamış Yüksek Lisans Tezi). Atatürk Üniversitesi, Erzurum.

ERDOĞAN, İ. (1991). İşletmelerde Davranış. İstanbul: İstanbul Üniversitesi İşletme Fakültesi Yayınları.

ERKUŞ, A. (1994). Psikolojik terimler sözlüğü. Ankara: Doruk Yayınevi.

EROĞLU, F. (2004). Davranış Bilimleri. İstanbul: Beta Basım A.Ş.

ERTÜRK, Y. D. (2010). Davranış Bilimleri. İstanbul: Kutup Yıldızı Yayınları.

ETIKAN, I., MUSA, S. A. ve ALKASSIM, R. S. (2016). Comparison of convenience sampling and purposive sampling. American journal of theoretical and applied statistics, 5(1), 1-4.

FIRAT, A. ve AYDIN, A. E. (2016). Hedonik Ve Faydacı Alışveriş Davranışı Üzerine Bir Araştırma. Journal of International Social Research, 9(43), 1840-1846.

GÜNEY, S. (2009). Davranış Bilimleri. Ankara: Nobel Yayın Dağıtım.

GÜVEN, E. Ö. (2009). Hedonik tüketim: Kavramsal bir inceleme. Anadolu Bil Meslek Yüksekokulu Dergisi, (13), 65-72.

HIRSCHMAN, E. C. ve HOLBROOK, M. B. (1982). Hedonic Consumption: Emerging Concepts, Methods and Propositions. Journal of Marketing, 46, 92-101.

KARAFAKIOĞLU, M. (2013). Pazarlama İlkeleri. İstanbul: Türkmen Kitabevi.

KARASAR, N. (2018). Bilimsel araștırma yöntemi. Ankara: Nobel Akademi Yayıncılık.

KOPTAGEL, G. (2001). Davranış Bilimleri. İstanbul: Nobel Tıp Kitabevleri. 
KÖK, S. B., ve AKSEL, İ. (2016). İş hayatında nicel başarı tanımlamasına bir karşı duruş: Erdem ahlâkı yaklaşımı. In International Conference on Eurasian Economies (pp. 140-149).

ODABAȘI, Y. (2017). Tüketim Kültürü: Yetinen Toplumdan Tüketen Topluma. İstanbul: Aura Kitapları.

ODABAȘI, Y. ve BARIŞ, G. (2002). Tüketici Davranışı. İstanbul: MediaCat Yayıncılık.

ODABAȘI, Y. ve BARIŞ, G. (2012). Tüketici Davranışları. İstanbul: MediCat Akademi.

ÖKTEM, U. (2009), İlköğretim Okullarında Görev Yapan Öğretmenlerin A Tipi Kişilik Özellikleri İle İş Doyumları Arasındaki İlişki (Yayınlanmamış Yüksek Lisans Tezi). Yeditepe Üniversitesi, İstanbul.

ÖZ, M. ve MUCUK, S. (2015). Tüketici satın alma davranışı kapsamında hedonik (hazcı) tüketimin plansız alışveriş üzerine etkilerinin incelenmesi. Pazarlama Teorisi ve Uygulamaları Dergisi, 1(2), 37-60.

ÖZGÜL, E. (2011). Tüketicilerin Sosyo-Demografik Özelliklerinin Hedonik Tüketim ve Gönüllü Sade Yasam Tarzları Açısından Değerlendirilmesi. Ege Academic Review, 11(1), 25-38.

SALTÜRK, M. (2008). Yönetim Başarısı ve Kişilik. İstanbul: Toplumsal Dönüşüm Yayınları.

SAYGIN, Y. (2014). Üniversite öğrencilerinin tevazu düzeylerinin denetim odağı ve kişilik özellikleri açısından incelenmesi (Yayımlanmamış doktora tezi). Necmettin Erbakan Üniversitesi, Konya.

SCHIFFMAN, L. G. ve KANUK, L. L. (2010). Consumer behavior. Upper Saddle River, NJ: Pearson Education.

SíLAH, M. (2005). Sosyal psikoloji (Davranış bilimi). Ankara: Seçkin Yayınları.

TAYMUR, I. ve TÜRKÇAPAR, M. H. (2012). Kişilik: Tanımı, sınıflaması ve değerlendirmesi. Psikiyatride Güncel Yaklaşımlar, 4(2), 154-177.

TEKIN, A. Ö. (2012). Yabancılaşma ve Beş Faktör Kişilik Özellikleri Arasındaki İlişkiler: Antalya Kemer'deki Beş Yıldızlı Otel İşletmeleri Çalışanları Üzerinde Bir Uygulama (Yayınlanmamış Doktora Tezi). Akdeniz Üniversitesi, Antalya.

TEZCAN, M. (1987). Kültür ve Kişilik. Ankara: Bilim Yayınevi.

TÜRK, M. S. (2007). Örgüt Kültürü ve İş Tatmini. Ankara: Gazi Kitabevi.

UDO-IMEH, P. T., AWARA, N. F. ve ESSIEN, E. E. (2015). Personality and Consumer Behavior: A Review. European Journal of Business and Management, 7(18), 98-106.

ÜNAL, S. ve CEYLAN, C. (2008). Tüketicileri hedonik alışverişe yönelten nedenler: İstanbul ve Erzurum illerinde karşılaştırmalı bir araştırma. Atatürk Üniversitesi İktisadi ve İdari Bilimler Dergisi, 22(2), 265-283.

VURAL, H. (2017). The relationship of personality traits with English speaking anxiety and English speaking self-efficacy (Yayımlanmamış yüksek lisans tezi). Gazi üniversitesi, Ankara.

YAKUT, Ö. (2006). Eğitim Yöneticilerinin Liderlik Davranışları ve Kişilik Özellikleri Arasındaki İlişkilerin İncelenmesi (Yayınlanmamış Yüksek Lisans Tezi). Yeditepe Üniversitesi, İstanbul. 
YAZGAN, B., BILGIIN, M. ve ATICI, M. (2004). Gelişsim Psikolojisi Çocuk ve Ergen Gelişimi. Ankara: Nobel Yayıncilık.

ZEL, U. (2011). Kişilik ve Liderlik. Ankara: Nobel Yayınları.

\section{EKLER}

Ek1. Kişisel Bilgi Formu

\section{KISISISEL BILGI FORMU}

Değerli Katılımcılar,

$\mathrm{Bu}$ araştırma İstanbul Ticaret Üniversitesi Reklam ve Stratejik Marka İletişimi Yüksek Lisans programı kapsamında yapılmaktadır. Soruların doğru veya yanlış cevapları yoktur. Verdiğiniz cevaplar kesinlikle gizli tutulacak ve sadece araştırma kapsamında kullanılacaktır. Araştırmanın doğru sonuç vermesi vereceğiniz gerçekçi ve içten cevaplara bağlıdır. Formda kimlik belirtmenize gerek yoktur, bireysel değerlendirme yapılmayacaktır.

Katkılarınızdan dolayı teşekkür ederim.

1. Cinsiyetiniz: $\operatorname{Kadin}($ ) $\operatorname{Erkek}($ )

2. Medeni Duuum: Evli(） Bekar ( ) Eşinden ayrılmı̨̧/Eşi vefat etmiş ( )

3. Yaşıuz: $18-25(\quad$ ) 26-35( ) 36-45( ) 46 ve üzeri ( )

4. Gelir diizeyiniz (aylk kazancmuz): $2500 \mathrm{TL}$ ve altı（） 2501-5000 TL（） 5001 TL ve üzeri ( )

5. Eğition Durumu (lïtfen son mezun oldığunuz proggamı işaretleyiniz):

Lise ( ) ÖnLisans ( ) Lisans ( ) Yüksek Lisans ( ) Doktora ( ) 
Sinan Öz, Erdem Tatlı, "Kişilik Özellikleri ile Hedonik Tüketim Değerleri Arasındaki İlişki Üzerine Bir İnceleme”, İzlek Akademik Dergi (Izlek Academical Journal), 4 (1), 2021, ss. 16-44.

Ek2. Hedonik Tüketim Nedenleri Değişkenleri Ölçeği

Benim için alışveriş bir maceradır

Alışverişi harekete geçirici bulurum

Alışveriş benim için bir heyecan kaynağıdır

Alışveri̧̧ bana kendi evrenimdeymişim gibi hissettirir

Çoğunlukkla indirimler varken alıșverișe giderim

Alı̧̧verişteyken indirimlere bakmaktan zevk alırım

Alışverişteyken ucuzlukları kovalarımi

Indirimli satışları yakalamak için alışverișe giderim

Başkaları için alıverişe çıkarım çünkü onlar kendilerini iyi hissederlerse bende kendimi iyi hissederim

Hayatımdaki özel insanlara bir şeyler aldı̆ı̆mda kendimi iyi hissederim

Arkadaşlarım ve ailem için alıșverişten zevk alırım

Birileri için mükemmel hediyeyi bulmak için etrafta alışveriş yapmaktan zevk alıım

Son trendleri görmek için alışverişe giderim

Yeni moda şeyleri takip etmek için alışverişe giderim

Piyasadaki yeni ürünleri görmek için alışverişe giderim

Yeni şeyler tecrübe etmek için alıșverişe giderim

Sosyalleşmek amacıyla alışverişe ailem ve arkadaşlarımla giderim

Alışverişteyken diğer insanlar ile sosyal iliş̧iler kurmaktan zevk alırım

Bana göre, ailemle ve arkadaşlarımla alışverişe çıkmak sosyal bir faaliyettir

Diğer insanlarla alışverişe çıkmak iliş̧kileri güçlendirici bir tecrübedir

Moralim bozuk olduğu zamanlarda, kendimi daha iyi hissetmek için alışverişe çıkarım

Bana göre, alışveriş stres atmanın bir yoludur

Kendim için özel bir şey yapmak istediğim zaman alışverişe çıkarım

Ek3. Sıfatlara Dayalı Kişilik Testi

Açıklama: Aşağıda bireyleri tanımak için kullanılan sıfat çiftleri verilmektedir. Sizden istenen, her bir sıfat çiftini okuyarak size uygunluk derecesine karar vermenizdir. Her sıfat çifti için bir tek daireyi doldurunuz. Doğru cevap yoktur, size uygun cevap vardır. Bunu dikkate alarak cevaplamaya çalışınız. Cevaplarınızı aşağıdaki örneklere göre belirtiniz.

\begin{tabular}{|c|c|c|c|c|c|c|c|c|}
\hline & 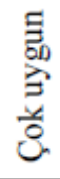 & 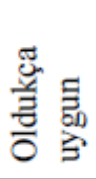 & 氙 & 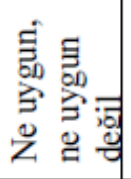 & 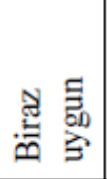 & 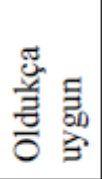 & 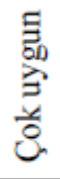 & \\
\hline İçedönük & $\circ$ & $\bullet$ & $\circ$ & $\circ$ & $\circ$ & $\circ$ & 0 & D1şadönük \\
\hline İçedönük & $\circ$ & 0 & $\circ$ & $\circ$ & $\circ$ & 0 & $\bullet$ & D1şadönük \\
\hline İçedönük & $\circ$ & $\circ$ & $\circ$ & $\bullet$ & $\circ$ & $\circ$ & $\circ$ & D1şadönük \\
\hline
\end{tabular}

$\mathrm{Bu}$ örneklerde,

1.Örnek kişi kendini oldukça içedönük olarak görmektedir,

2.Örnek ise kişi kendini çok dişadönük olarak görmektedir,

3.Örnek ise kişi bu boyutlarda kararsızdır veya her iki sıfatı da kendine uzak veya yakın görmektedir, anlamına gelmektedir.

\begin{tabular}{|c|c|c|c|c|c|c|c|c|c|}
\hline & & 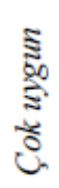 & $\begin{array}{l}\frac{5}{3} \\
\frac{3}{3} \\
0\end{array}$ & 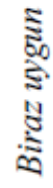 & 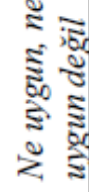 & 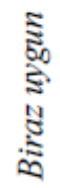 & 总 & 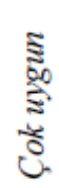 & \\
\hline 1 & Sakin & $\circ$ & $\circ$ & 0 & $\circ$ & 0 & $\circ$ & $\circ$ & Sinirli \\
\hline 7 & Silik & $\circ$ & $\circ$ & $\circ$ & $\circ$ & $\circ$ & $\circ$ & $\circ$ & Atak \\
\hline 21 & İyimser & $\circ$ & $\circ$ & $\circ$ & $\circ$ & $\circ$ & $\circ$ & $\circ$ & Karamsar \\
\hline 40 & İnatç1 & $\circ$ & $\circ$ & $\circ$ & $\circ$ & $\circ$ & $\circ$ & $\circ$ & Uzlaşmac1 \\
\hline
\end{tabular}

